\title{
Sustainable Supply Chain and Innovation: A Review of the Recent Literature
}

\author{
Letizia Tebaldi, Barbara Bigliardi $[$ and Eleonora Bottani * \\ Department of Engineering and Architecture, University of Parma, viale delle Scienze 181/A, 43124 Parma, \\ Italy; letizia.tebaldi@studenti.unipr.it (L.T.); barbara.bigliardi@unipr.it (B.B.) \\ * Correspondence: eleonora.bottani@unipr.it
}

Received: 9 August 2018; Accepted: 26 October 2018; Published: 30 October 2018

\begin{abstract}
Increasingly, the effects of supply chains on environmental issues have been a focal point in discussions involving stakeholders, authorities, and customers. The aim of this paper is to inspect how innovation and sustainability are integrated into the wider context of the supply chains. To this end, a systematic literature review was carried out with a particular focus on papers published in recent years (2015-2017) so as to continue from a previous review on the sustainable supply chain innovation topic covering the time span of 1996-2014. The descriptive aspects of the published papers are firstly examined, i.e., the year of publication, journal, research methodology, industry field and country of the study, followed by the thematic ones, i.e., key themes of the innovation process, the types of innovation found, their newness, dimensions, and main theories that emerged. The analysis shows an upward trend of literature in numerical terms and a wider spread of sustainable innovations. Additionally, the research highlights further areas of research that are deserving of attention. These areas include analyses of specific industrial sectors which have been less covered in the published literature; research activities in the less developed countries; more attention on the social dimension of sustainability; a more general contribution from some nations that turned out to be less productive or even inactive on the sustainable supply chain innovation topic. Finally, a framework is developed which could constitute the basis for further developments and research on this issue.
\end{abstract}

Keywords: innovation; sustainability; supply chain; systematic literature review; framework

\section{Introduction}

With a growing market demand for various products in the latter half of the 20th century, many organizations ventured into risky but frugally profitable modes of production, compromising long-term impacts both on society and the environment [1]. This fact, in addition to the several accidents that have occurred, such as the Chernobyl disaster in 1986 or the famous oil tanker Amoco Cadiz sink in 1978 and many others, led the United Nations to coin the term sustainable development during the Conference on the Human Environment in 1972 [2], which can be inserted in the business context as meeting the needs of firm's direct and indirect stakeholders without compromising its ability to meet the needs of future stakeholders as well [3]. Some years later, in 1987, the opportunities for sustainability innovation received wide attention with the Brundtland Report [4]. Hence, stakeholders, including regulatory authorities, manufacturers, customers, and the public, were forced to reconsider economic business models and to question the implications of business practices on society and the environment [1]; the depletion of the Earth's finite resources through increased consumption, industrialization, and globalization caused organizations to reconsider how they should compete in the coming years and decades [5]. 
Increasingly environmental issues were recognized as sources of strategic change [6], ecological factors became part of innovation research [7-9], and eco-innovation practices such as cleaner production, life cycle assessments, and eco-design found their way into firms [10,11].

The effects of supply chains on environmental issues have been a focal point in recent discussions [12] and research in the area of sustainable supply chain management (SSCM) has evolved over the past few decades [13]. SSCM is essentially an extension of GSCM (Green Supply Chain Management), i.e., the integration of environmental thinking into supply chain management [14] that comprises economic, environmental, and social concerns [15].

A more sustainable supply chain performance is indicated by a company's capacity to reduce the use of materials, energy, or water and to find solutions that are more eco-efficient by improving the management of their supply chains [16]. Several firm leaders are working hard to propose the optimal design of the sustainable supply chain in order to respect the environmental constraints and maximize profit [17] and, at the same time, there is a growing pressure on supply chain managers to provide economical and innovative solutions through waste reduction and the development of new "clean" technologies in order to support the organization's goals and strategic objectives and pacify stakeholders [18,19]; future supply chains will have to be designed to reduce energy consumption and $\mathrm{CO}_{2}$ emissions [12,20]. In this context, the concept of Reverse Supply Chain Management (RSCM) has been developed as an adaptation of the modern circular economy principles to supply chain management. An RSC includes activities dealing with product design, operations, and end-of-life management aimed at to maximizing value creation over the entire lifecycle through value recovery of after-use products either by the original product manufacturer or by a third party [21]. RSCs are either open-loop or closed-loop; basically, open-loop supply chains involve materials recovered by parties other than the original producers who are capable of reusing these materials or products. On the other hand, closed-loop supply chains (CLSC) deal with the practice of taking back products from customers and returning them to the original manufacturer for the recovery of added value by reusing the whole product or part of it [21,22]; this last configuration is applied to many industries to help managers and scholars understand how the recycling system affects the entire supply chain and each supply chain member [23].

A clear definition that integrates the three concepts of innovation, sustainability, and the supply chain did not exist before the systematic literature review published in 2017 by Gao and colleagues [24]. These authors clarified that the idea of Sustainable Supply Chain Innovation (SSCI) comes from the root Supply Chain Innovation (SCI), which can be defined as an integrated change from incremental to radical changes in the product, process, marketing, technology, resource and/or organization, which are associated with all the related parties, covering all related functions in supply chain and creating value for all stakeholders. If the SCI results in the balanced performance of economic, social and environmental dimensions, meaning that all three dimensions have positive innovation performance, then it is called an SSCI [24]. The linkage between the innovative firm and its supply chain is even more important when one considers that a sustainable supply chain is one of the few remaining ways for a company to achieve a sustainable competitive advantage [25]; therefore, sustainable innovations have to go beyond the single firm and include the whole chain. In today's business world, in fact, competition is no longer between firms, but between supply chains to enhance a competitive advantage [26].

On the basis of the considerations reported above, this paper tries to inspect how innovation and sustainability are integrated into the wider context of supply chains. To this end, a systematic review of the literature published in 2015, 2016, and 2017 years is carried out. The choice for the time span is that a previous review by Gao et al. [24] targeted papers published from 1996 to 2014. We opted to continue this previous work because of the relevance of the topic and the rapid growth of literature: in fact, 122 papers published from 2015 to 2017 are reviewed in this manuscript, vs. 107 papers published in the 19 years reviewed in the previous study. A systematic literature review is chosen as the research methodology as it is an effective tool for managing the diverse knowledge base for academic inquiry, for summarizing the available outcomes, and for defining further developments of the existing body of literature [27]. Specifically, this review analyzes the literature from a descriptive point of view and a 
thematic one, to emphasize differences with the previous years, evaluate progress, and underline the areas where further research activities are needed. Overall, this study aims to answer the following question: how is research evolving in the field of SSCI?

The organization of the paper is as follows. Section 2 illustrates the methodology used to carry out the review, while Section 3 details the review results. The main findings of the study, discussions, and conclusions, including limitations as well as future research steps, are presented in Section 4.

\section{Methodology}

In carrying out the review, we adopted the model proposed by Mayring [28] for the sake of consistency with the previous analysis by Gao et al. [24]. This model consists of four main steps, i.e., material collection, descriptive analysis, category selection and, finally, material evaluation; in our approach, these steps correspond to data collection (material collection) and data analysis (descriptive analysis, category selection, and material evaluation).

\subsection{Data Collection}

A query on the Scopus (www.scopus.com) and Web of Science (webofknowledge.com) databases was carried out using "sustainability", "innovation" and "supply chain" as keywords. Scopus was chosen because of its extensive coverage of over 22,000 journals from the main publishers of peer-reviewed papers, like Springer, Elsevier, Emerald, Inderscience, Wiley, and others [29]; in addition, papers collected from Web of Science were included as well, in order to refine the results, as well as for the sake of consistency with the study by Gao et al. [24]. Constraints were set on the language of the paper (English), publication type (journal paper) and time span (2015-2017).

The papers obtained were first screened by looking at the title to remove duplicates, i.e., studies that were returned from both databases. The remaining papers were analyzed by reading the abstract to evaluate their relevance to the present study. More precisely, papers focusing on topics other than the integration of innovation and sustainability or not approaching these topics from a supply chain perspective were excluded from the review. The final number of papers retained for the analysis is 122 .

\subsection{Data Analysis}

Firstly, a set of descriptive statistics was carried out to provide an overview of the targeted literature in terms of the publication year, journal, research methodology, industry field, and country of the study [24]. As far as the content is concerned, the thematic analysis starts by illustrating the various phases and key themes of the innovation process, then identifies the various types of innovation met during the analysis, their respective newness (i.e., radical or incremental), and dimension (i.e., economic, environmental or social); the last part focuses on the main applied theories emerged during the review process. The attention is therefore given to the innovation process itself rather than to its function in the supply chain.

From the sample of articles reviewed, the most popular sustainable practices, drivers to eco-innovation, and barriers against its implementation were extrapolated; these elements form the basis for the framework developed in Section 4, which will be useful to carry out future research activities.

\section{Review Results}

\subsection{Descriptive Analysis}

Descriptive statistics about the publication year of the articles reviewed are illustrated in Figure 1. The same figure also shows the results of the previous review for the nineteen years from 1996 to 2014, for a better understanding of the publication trend. As Figure 1 shows, 23 articles were published in 2015, 40 in 2016 and 59 in 2017; 2017 emerges as the more productive year overall. It is therefore clear that the literature discussing innovation and sustainability is gradually growing; although this 
result could be a consequence of the general growth of literature on green marketing, green accounting, green retailing, GSCM, and green general management [30], we think that this rapid increase in the number of papers published deserves attention. Overall, in just ten years, the number of publications has increased by seven times, in line with Gao et al. statement: we might be able to predict that the rapid growth stage of the research in sustainable supply chain innovation is soon approaching [24].

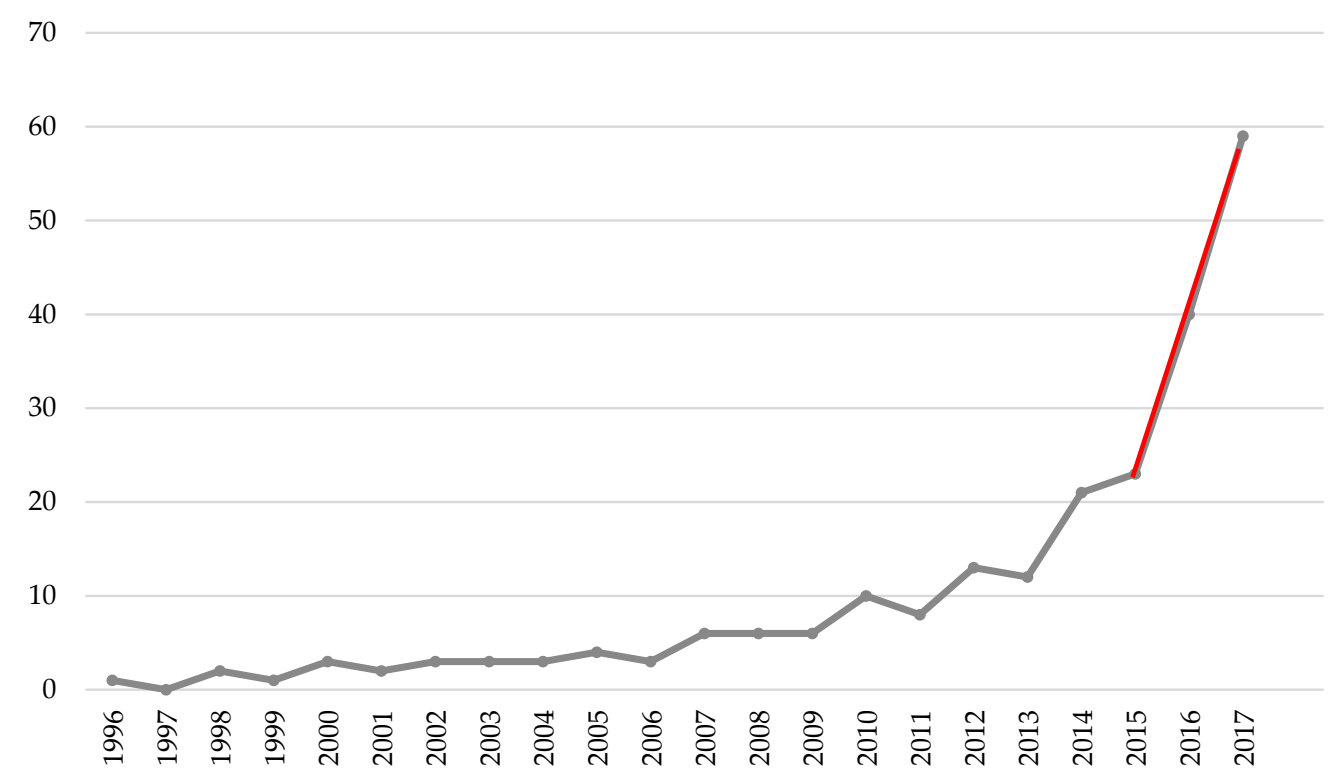

Figure 1. The evolution of the number of reviewed studies over time. The red line refers to our time span.

Table 1 lists the journals where the reviewed articles were published; to be more effective, the list is limited to journals that published at least two papers. Overall, 64 journals were recorded in this triennium for 122 articles against 68 journals of the previous nineteen years for 107 articles. Out of the 68 journals found in the previous review, 12 also published papers in 2015-2017, while no publications were found from the remaining 56 journals. The journal that published most of the studies included in the review is the Journal of Cleaner Production (29 papers, $23.8 \%$ of the total articles, compared to $6.5 \%$ which covered in the previous review), followed by Sustainability (17 papers, around $14 \%$ of the total articles, compared to 0 papers in the previous review), and the International Journal of Production Economics ( 5 papers, $4.1 \%$ of the total articles, compared to the 7 papers in the previous analysis). Five journals published 2 articles, while the remaining journals published just one paper. It is interesting to note that Sustainability is a relatively new journal, launched in 2009, and was, nonetheless, found to be one of the most productive journals on the themes of this review.

Table 1. The distribution of reviewed papers by journal name.

\begin{tabular}{|c|c|c|c|c|}
\hline \multirow{2}{*}{ Source } & \multicolumn{3}{|c|}{ Publication Year } & \multirow{2}{*}{ TOTAL } \\
\hline & 2015 & 2016 & 2017 & \\
\hline Journal of Cleaner Production & 6 & 8 & 15 & 29 \\
\hline Sustainability & 1 & 5 & 11 & 17 \\
\hline International Journal of Production Economics & 2 & 2 & 1 & 5 \\
\hline Renewable and Sustainable Energy Reviews & 1 & 2 & 1 & 4 \\
\hline Supply Chain Management: an International Journal & 2 & 0 & 1 & 3 \\
\hline Benchmarking: an International Journal & 0 & 2 & 0 & 2 \\
\hline Biomass and Bioenergy & 1 & 0 & 1 & 2 \\
\hline Energies & 0 & 0 & 2 & 2 \\
\hline Resource, Conservation, and Recycling & 1 & 0 & 1 & 2 \\
\hline Transportation Research Part D & 0 & 0 & 2 & 2 \\
\hline
\end{tabular}


The third parameter considered in the descriptive analysis was the methodology used by the authors to carry out their research. According to Seuring and Müller [31], five research methodologies were identified: (1) theoretical and conceptual papers; (2) case studies; (3) empirical surveys; (4) modeling papers; and (5) literature reviews. Figure 2 shows the classification of the papers reviewed by the research methodologies, while Appendix A classifies the papers reviewed according to the methodology applied.

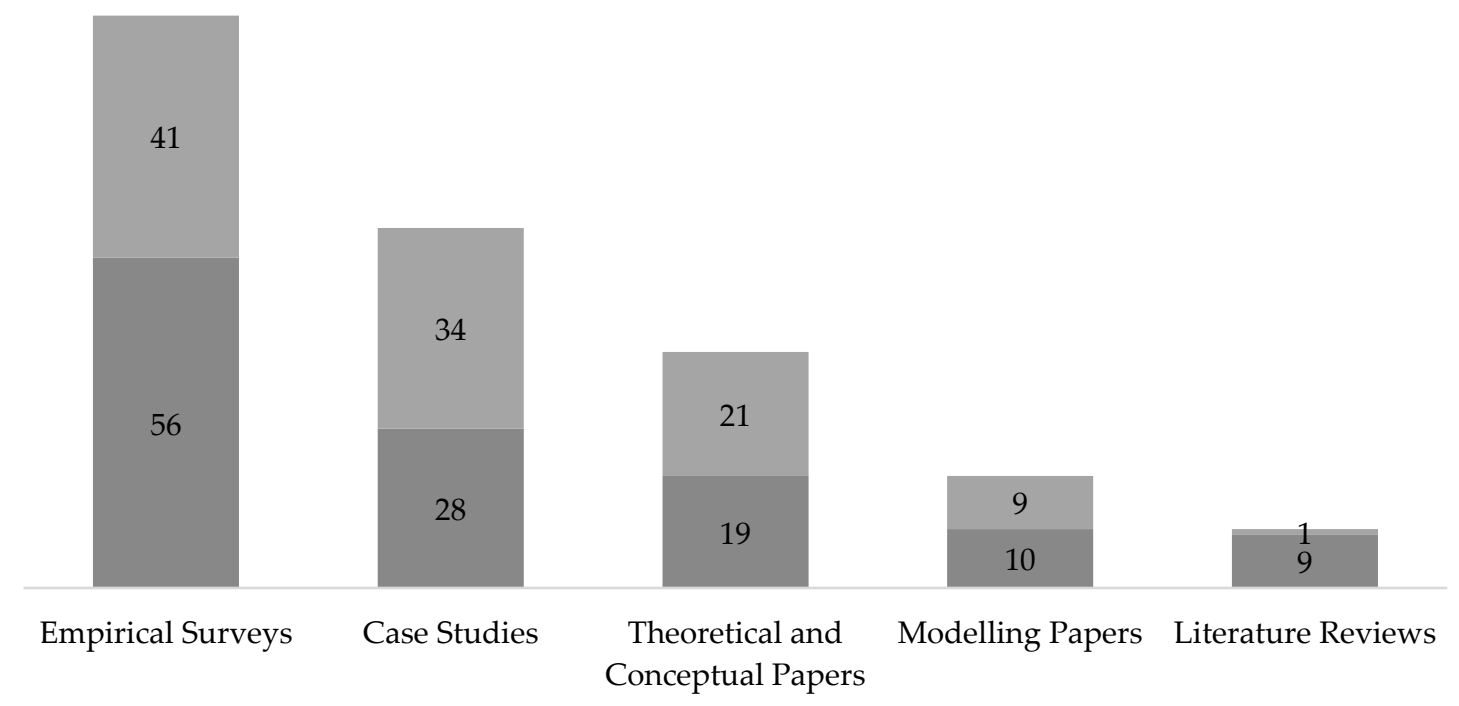

Figure 2. The research methodology applied, reported in order of the articles' decreasing number. Note: light gray represents the results from the previous review.

From the classification, empirical surveys emerged as the most widely used methodology, adopted in 56 cases, followed by case studies, used in 28 papers ( 16 multiple case studies, 12 single case studies). These two empirical methods that were taken together cover $68.9 \%$ of the total number of articles; this result is in line with the previous review, where surveys and case studies covered $38.3 \%$ and $31.8 \%$ of the articles reviewed, respectively. A noteworthy positive element is the fact that 9 literature reviews were also found (including the one by Gao et al.), against only one review reported by Gao et al. This is a further important symptom of the increase in the literature related to the topic investigated: in fact, as review studies requires a significant number of articles to be carried out, the presence of a relevant number of reviews leads to the conclusion that the literature on innovation and sustainability has expanded significantly. Nonetheless, a direct comparison of the present study with the eight reviews available in the literature is not always possible, since these studies concerned very specific areas of SSCI, which cannot be directly related to the topic of this review. Examples of this areas include collaborations aimed at sustainability among different actors of the supply chain, green marketing analyses, new products development, or new technology for pruning harvesting.

To classify the industrial sector, the International Standard Industrial Classification (ISIC) has been taken as the reference. This international system for partitioning economic activities edited by the statistic department of the United Nations is articulated in 21 sections, which, in turn, includes divisions, groups, and classes [32]. The N, S, R, O and P sections were grouped into one main class, named $S$ (service activities), as done by Gao et al. Two further sections were added based on the material: $\mathrm{V}$, which includes multiple sectors, and $\mathrm{X}$, when no specific sector is mentioned, which is often the case for literature reviews. Figure 3 shows the distribution of the industrial sectors considered in the papers reviewed, while in Figure 4, the evolution over the three years related to the fields is depicted; the detailed classification of these papers per industrial sector is reported in Appendix B. 


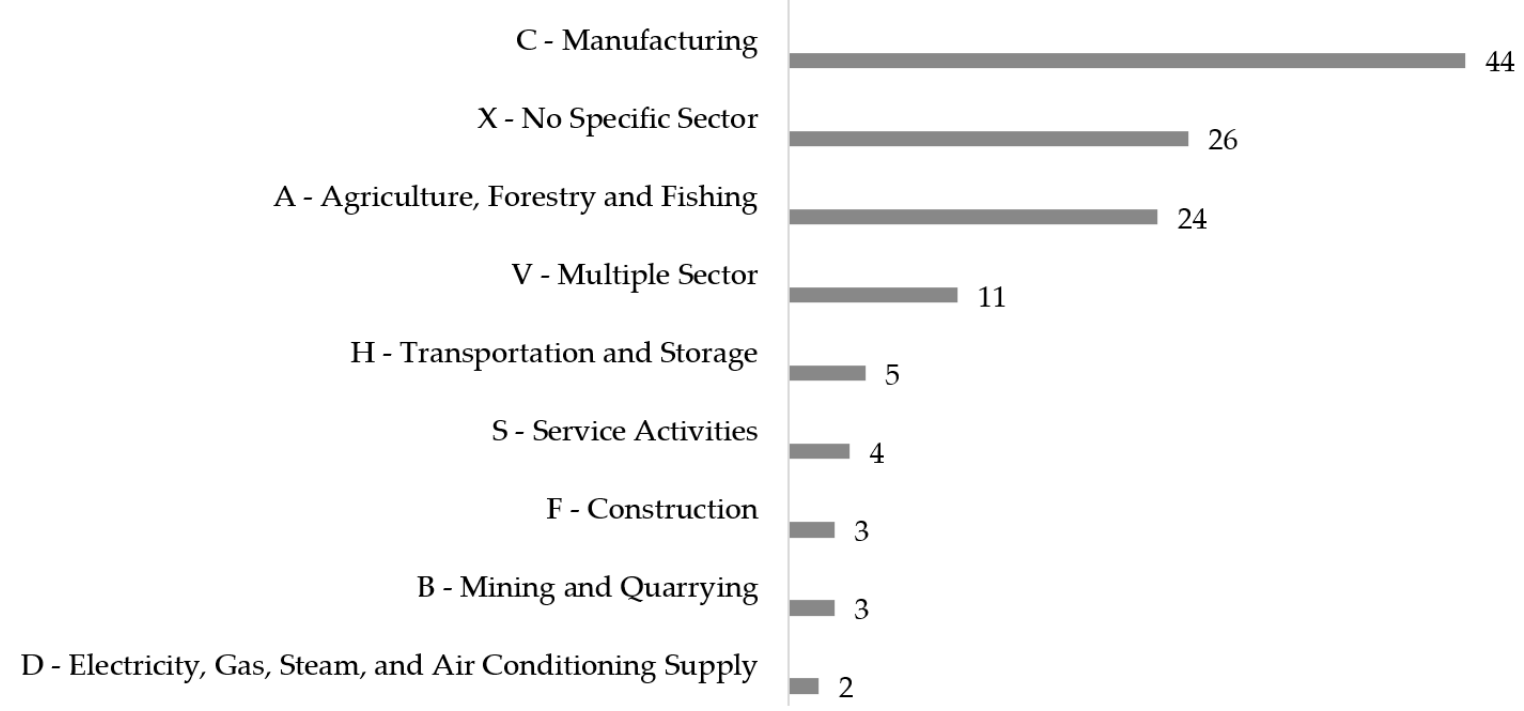

Figure 3. The industrial sectors.

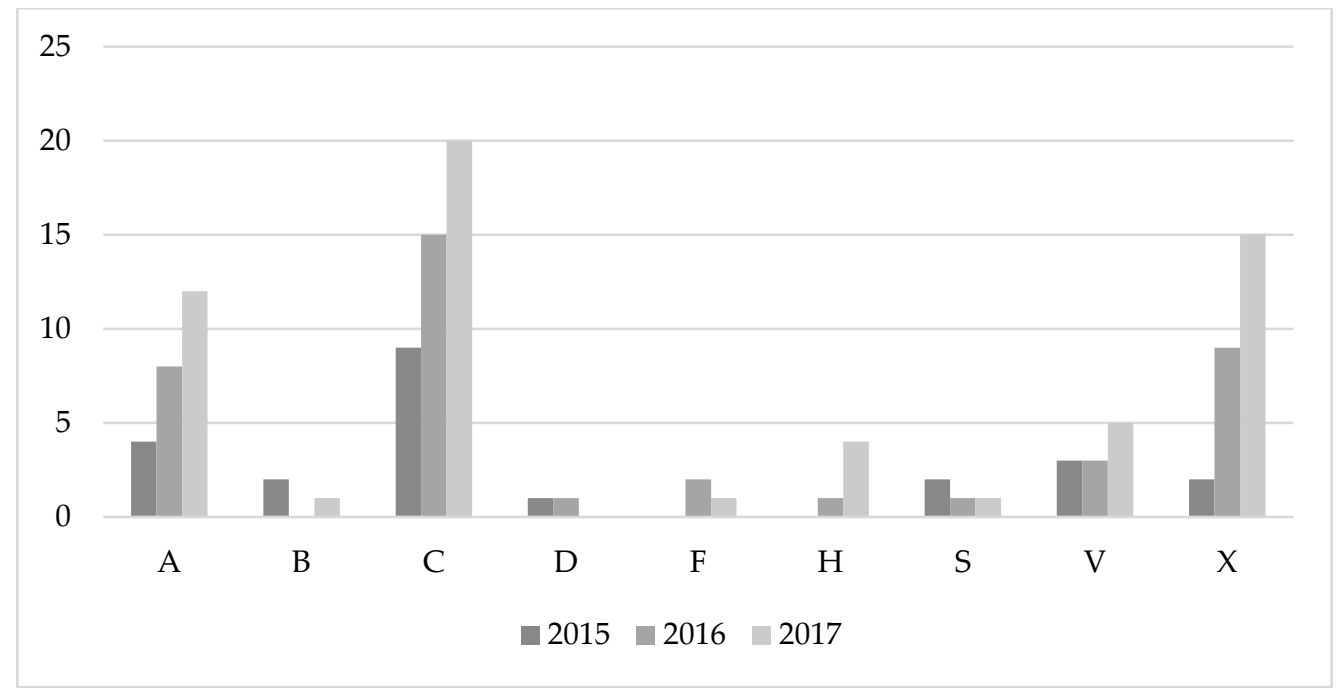

Figure 4. The industrial sectors related to the year of publication.

The manufacturing sector, whose firms are perceived to generate stronger social and environmental impacts [33] and whose harms must decrease by 50 times [34], is the most popular sector in the sample of papers reviewed, covering $36 \%$ of the articles analyzed. This value shows an increase compared to the previous review by Gao et al., where the manufacturing sector covered $32 \%$ of the papers analyzed. The reason for this popularity is twofold: first, the manufacturing sector is the wider and most important sector in the ISIC classification, including 24 divisions, 71 groups, and 189 classes [32], and covers approximately one-quarter of the total activities. Second, production is a key function for value creation within the supply chain, whose data are easily available [24]. Therefore, it has attracted attention in the field of innovation and the sustainability of the supply chain. Numerous articles (26) belong to the $\mathrm{X}$ section, meaning that they do not refer to any particular sector. Finally, around $20 \%$ of the papers reviewed focus on the agricultural, forestry, and fishing activities. This sector too has experienced an increase in popularity compared to the previous review, where it covered $8.4 \%$ of the studies reviewed, probably because it is closely related to the environment and, therefore, worthy of consideration on the topic of the willingness to reduce polluting emissions.

As far as the geographical distribution of the papers is concerned, the first author's nationality was considered as Gao et al. did. For 9 authors it was not possible to determine the exact nationality: 
hence, the institution of origin was considered as the origin of the study; generally, the authors' nationality coincided with the institution of origin, whilst only differing in 17 cases. Nations that contributed with at least two publications are listed in descending order in Figure 5 and Table 2. The GNP (Gross National Product) is also reported in this table, with the relative percentage invested in Research \& Development (R \& D) in 2015 (first year of this review); related data was retrieved from the "Global R \& D Funding Forecast" [35]. The investments in R \& D were reported because of their relationship with the innovation developed by a country. A similar relationship has been identified with sustainability, with the amount of investments in 2014 and 2016 reported in Table 3, as elaborated by "Global Sustainable Investment Review" [36].

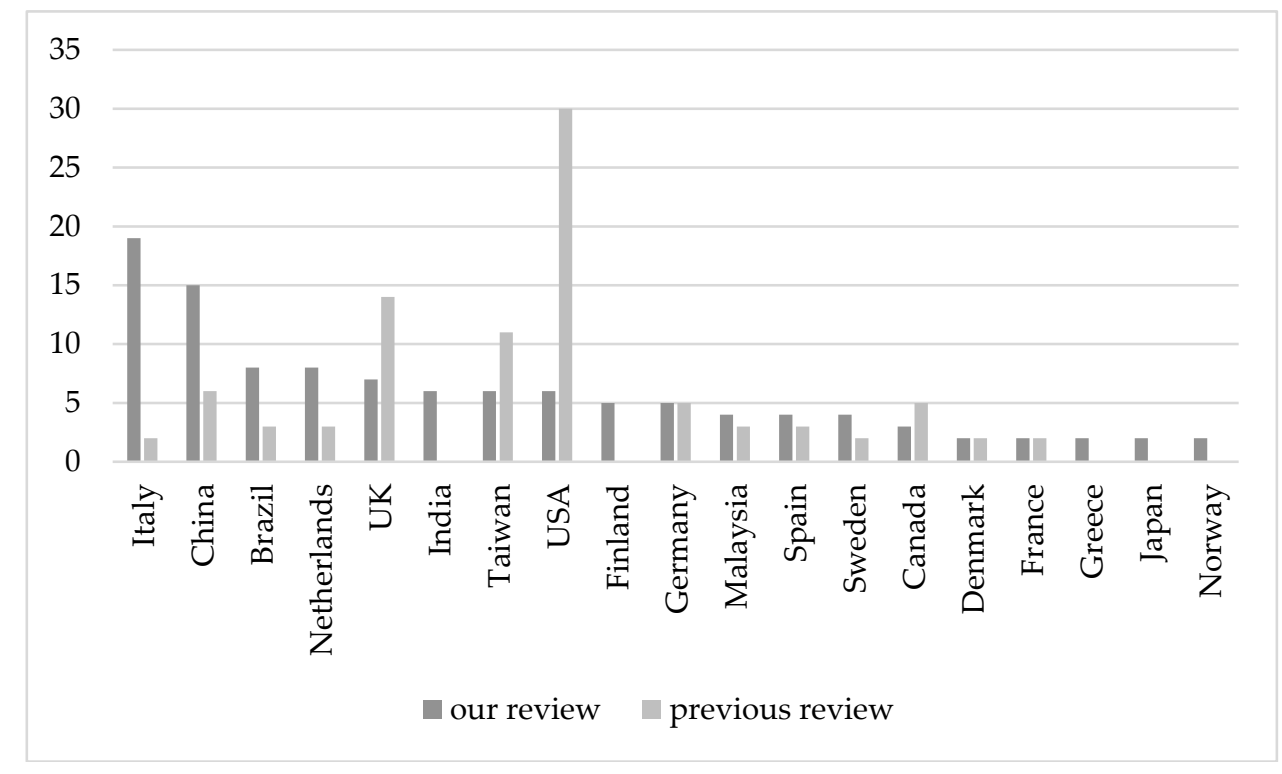

Figure 5. The geographical distribution, countries with two publications or more.

Table 2. The GNP and GNP's percentage invested in R \& D.

\begin{tabular}{ccc}
\hline Country & GNP (Bil, US\$) & \%GNP in R \& D \\
\hline Italy & 2171.0 & 1.27 \\
China & $19,390.0$ & 1.92 \\
Brazil & 3192.0 & 1.21 \\
The Netherlands & 832.6 & 2.16 \\
UK & 2679.0 & 1.78 \\
India & 7965.0 & 0.85 \\
Taiwan & 1099.0 & 2.35 \\
USA & $17,950.0$ & 2.77 \\
Finland & 225.0 & 3.55 \\
Germany & 384.0 & 2.92 \\
Malaysia & 815.6 & 1.10 \\
Spain & 1650.0 & 1.30 \\
Sweden & 474.4 & 3.40 \\
Canada & 1632.0 & 1.79 \\
Denmark & 258.7 & 2.98 \\
France & 2647.0 & 2.26 \\
Greece & 194.9 & NA \\
Japan & 4830.0 & 3.41 \\
Norway & 356.2 & 1.65 \\
\hline
\end{tabular}


Table 3. The amounts of investments towards sustainability in 2014 and 2016. Values are expressed in billions (dollars).

\begin{tabular}{cccc}
\hline Region & $\mathbf{2 0 1 4}$ & $\mathbf{2 0 1 6}$ & $\begin{array}{c}\text { \% } \\
\text { Growth }\end{array}$ \\
\hline Europe & 10,775 & 1204 & 11.7 \\
United States & 6572 & 8723 & 32.7 \\
Canada & 729 & 1086 & 49.0 \\
Australia/New Zealand & 148 & 516 & 247.5 \\
Asia (ex. Japan) & 45 & 52 & 15.7 \\
Japan & 7 & 474 & 6689.6 \\
\hline
\end{tabular}

The podium is occupied by Italy with 19 articles published, 16 of which come from Italian institutions. The top five positions, i.e., the first eight countries considering the ex aequo, also fall in the top ten GNP values, with the only exceptions being Taiwan and The Netherlands which, however, invest more than $2 \%$ of their GNP in R \& D, showing high funding in research and Italy, investing $1.27 \%$ of its GNP: one of the lowest percentage values but, at the same time, they have quite a high number of publications. The United States is rather lacking, especially if we consider their wealth, potentialities, and investments towards both sustainability and R \& D; similar considerations hold true for Japan, despite its huge increase in sustainable issues during the period under review. Brazil's commitment is, again, positive, since it is a leading emerging country in environmental challenges [37] and it is one of the most economically important countries in Latin America, contributing to $7 \%$ of the world's GNP [16].

If we compare these findings with the previous results by Gao et al., the relative importance of the United States totally falls short since this country was at the first place for the number of articles with 30 publications on the innovation and sustainability of supply chain, despite their $2.77 \%$ investment in research. It is worth noting that developing economies like China, Taiwan, or Malaysia are still among the first places in the ranking and, with India as well, they have now become fearful competitors with the most developed countries [38]; Australia disappeared from the top ten positions though, in the previous review, it was in the fourth place with 7 papers. The contribution of Italian authors has clearly increased. In terms of the investments in R \& D, Finland and Denmark's commitment stands out, confirming Europe's good work in this direction. The lack of South Korean research into innovation and sustainability is amazing since $4.04 \%$ of its GNP supports R \& D, which is the highest percentage with Israel's 3.95\%.

What emerges from this analysis is the urgency of research activities by low-income countries, where there are many sustainability issues, and these issues offer a wide range of related research opportunities that should not be overlooked [39]; just think about the fact that by 2050 the combined GDP of the emerging economies will be more than 50 percent of the total GDP of the world [40].

\subsection{Thematic Analysis}

The thematic analysis begins with the analysis of the key themes in each phase of the innovation process, which can be separated into pre-innovation, innovation, and post-innovation [24]. Therefore, the articles were first divided into three groups depending on the main argument, then the contents were examined. Nine articles were excluded from this last step since they were literature reviews and, therefore, did not refer to any specific phase of the innovation process. Results are shown in Table 4. 
Table 4. The number of articles in each phase.

\begin{tabular}{cc}
\hline Phase & Number of Articles \\
\hline Pre-innovation & 42 \\
Innovation & 51 \\
Post-innovation & 20 \\
N.A. & 9 \\
\hline
\end{tabular}

As it is easy to see from the graph in Figure 6, most of the articles (approx. 77\%) concern pre-innovation and innovation issues; only 20 papers focus on the post-innovation theme.

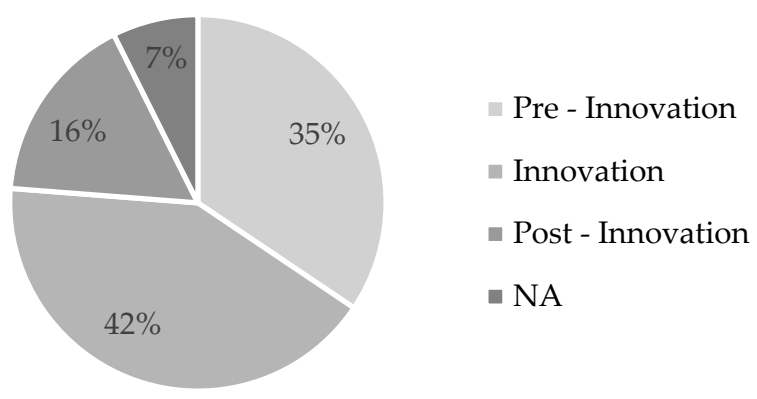

Figure 6. The percentage of articles in each phase.

The key themes in pre-innovation phases are, as expected, the ones focusing on barriers and obstacles to sustainable innovation or those that motivate sustainable innovation. The former has a fundamental role as a better understanding of the potential barriers to the corporate environmental management can be useful during decision-making processes and to drive decisions regarding the prioritization of issues that deserve attention from managers and policymakers towards a more sustainable society [41]. Among the main barriers, the scarcity of resources, high costs, complexity, risks and, above all, the uncertainty regarding future results can be enumerated [42]. A clear understanding of barriers will help organizations to prioritize and to manage their resources in an efficient and effective way [43]. The contents instead related to boosting sustainable innovation support the sharing of information among the different actors of the supply chain, their communication, and their collaboration. The latter is gaining increasing attention [44], in fact, too often do large retailers ask suppliers for a better environmental performance at ever-lower prices without sacrificing the product quality or making contribution efforts [45], leading to the results being poor. Several studies show that collaborations have a positive impact on the greater environmental and economic performance [46], as well as on the institution, environmental laws, and regulations on the relationships between firms in sustainable supply chains [47]. A cooperating strategy among the suppliers, customers, other organizations, and even competitors is therefore required, together with data sharing and communication

In the innovation phase, the key issues merely cover innovation implementation with its main features and difficulties (e.g., References [48,49]), and the evaluation of its current trend; these are the most common topics in the literature (51 papers).

Finally, the key themes in the post-innovation phase deal with the final assessments and considerations on innovation implementations and this is the less-examined in-depth part, despite the attention it had in the previous period (43 papers); this can be justified by the previous statement referring to the temporal evolution of the subject. Most of the articles related with this phase concern follow-up assessments on implementation (e.g., References $[50,51])$ rather than steps to be followed after the introduction of innovation (e.g., Reference [13]). Appendix $C$ lists the references according to the different phases of innovation.

In the 122 papers, 108 innovations were identified, or more precisely, in exactly 66 papers, since no innovations were recognized in 56 papers and, accordingly, these articles were excluded from this 
part as well as from the subsequent analysis of novelty and dimension of innovation. The following five categories of innovation were identified: product innovation, process innovation, organizational innovation, marketing innovation, technological innovation, resource allocation innovation. The first four categories refer to the classification proposed by different authors (e.g., Reference [52]). Specifically, product and process innovations are generally defined "technological innovations", while organizational and marketing innovations are referred to with the term "non-technological innovations". The fifth category identified in our review, that is, technological innovation, is expressively referred to mainly as radical novelties such as RFID tools (e.g., Reference [53]) or e-learning platforms (e.g., Reference [54]), not to be confused with similar kinds of product or process innovation, as defined by previous studies [55,56], that sometimes overlap [24]. Finally, resource allocation innovation refers to a resources' redistribution in order to achieve innovative results. Table 5 reports the definitions for each type of innovation.

Table 5. The definition of each type of innovation.

\begin{tabular}{clc}
\hline $\begin{array}{c}\text { Type of } \\
\text { Innovation }\end{array}$ & \multicolumn{1}{c}{ Definition } & Source \\
\hline $\begin{array}{c}\text { Product } \\
\text { Innovation }\end{array}$ & Any goods, service, or idea that is perceived by someone as new & {$[55,56]$} \\
\hline $\begin{array}{c}\text { Process } \\
\text { Innovation }\end{array}$ & $\begin{array}{l}\text { The adaptation of existing production lines as well as the } \\
\text { installation of an entirely new infrastructure and the } \\
\text { implementation of new technologies; it generally allows for the } \\
\text { creation of new products }\end{array}$ & {$[55,56]$} \\
\hline $\begin{array}{c}\text { Organizational } \\
\text { Innovation }\end{array}$ & $\begin{array}{l}\text { Changes in marketing, purchases, sales, administration, } \\
\text { management, staff policy }\end{array}$ & {$[55-57]$} \\
\hline $\begin{array}{c}\text { Marketing } \\
\text { Innovation }\end{array}$ & Improvements in product design, placement, promotion or pricing & {$[55,56,58,59]$} \\
\hline $\begin{array}{c}\text { Technological } \\
\text { Innovation }\end{array}$ & $\begin{array}{l}\text { Any contemporary idea, practice, or product that an organization } \\
\text { wishes to adopt and employ for the purpose of obtaining gains in } \\
\text { performance }\end{array}$ & {$[24,60,61]$} \\
\hline $\begin{array}{c}\text { Resource } \\
\text { allocation } \\
\text { Innovation }\end{array}$ & A resource redistribution in order to achieve innovative results & {$[62,63]$} \\
\hline
\end{tabular}

The resulting classification is presented in Figure 7, while Appendix D shows the references in relation to the novelty of each innovation. 


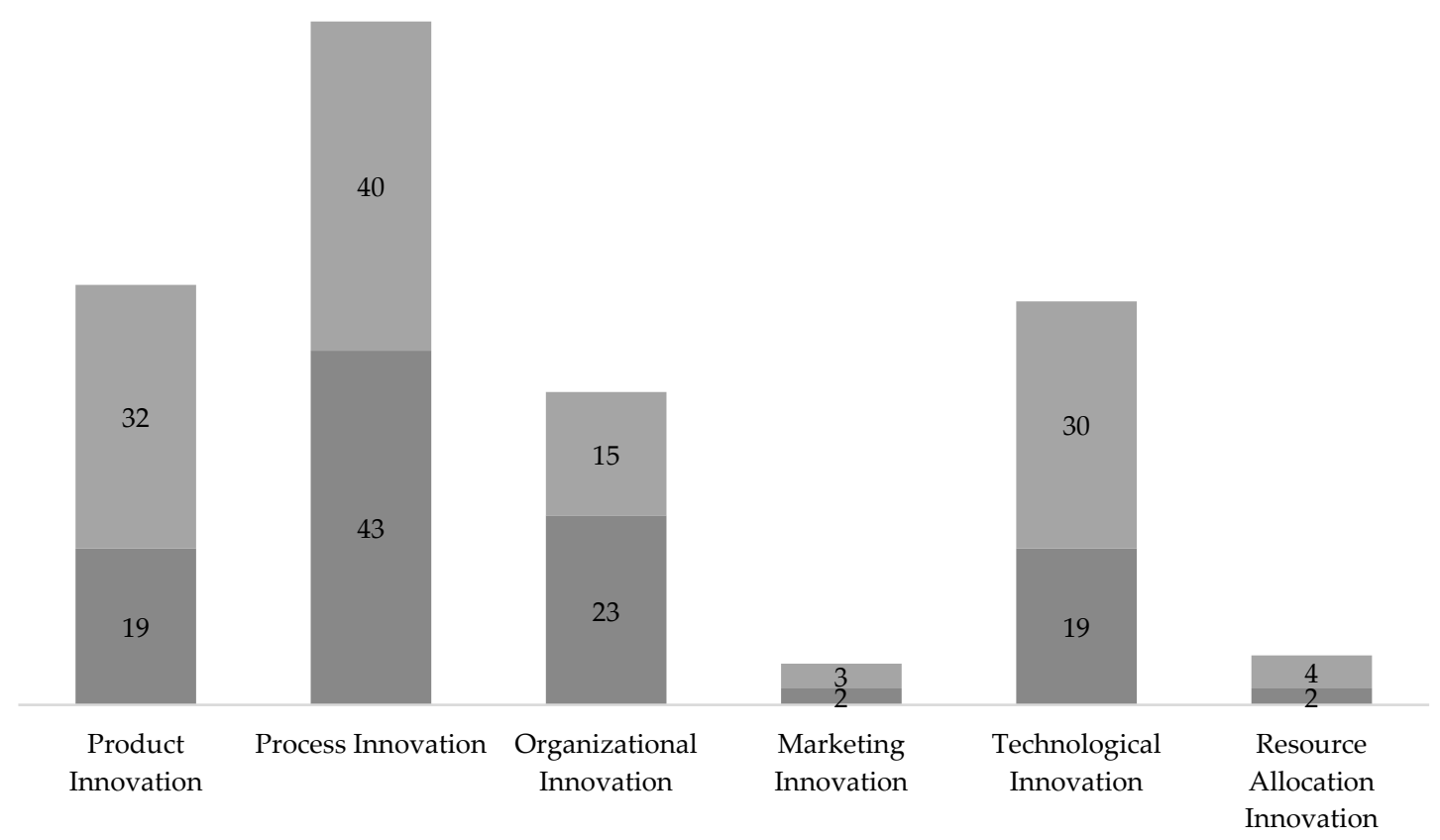

Figure 7. The types of Innovation. Note: light gray represents the results of the previous analysis.

Process innovation is once again the most common type of innovation highlighted in the literature review; particular attention was paid to innovations related to processes such as biogas, biomass, biodiesel, or biorefineries (e.g., References [62,64]). Organizational innovations follow, including collaborations among different actors of the supply chain, primarily suppliers, which allow profit maximization and high levels of eco-efficiency [45].

Regarding product innovation, we mainly talk about eco-design, with particular attention to the packaging since it corresponds to $30-35 \%$ of the municipal solid waste yearly generated in industrialized countries [65]. Less attention was paid to remaining types: marketing innovations refer to "green marketing", so directed in order to identify segmentation, targeting, positioning, differentiation (e.g., Reference [66]) addressed to promote products and sustainable actions made by firms; finally, resource allocation innovations were found in just two cases, in articles where different scenarios for sustainable innovations were outlined.

Regarding the novelty of each innovation, researchers usually classify innovation as radical and incremental. An innovation is defined as radical when existing practices or models are destroyed or supplanted, and something entirely new (i.e., not existing before) is introduced; examples of radical innovations can be the Aquaponics production system, which plays a crucial role in the future of environmental and socio-economic sustainability in smart cities [67], or the use of 3D printing (3DP) for the creation of a Circular Economy [68]. Instead, incremental innovation denotes a series of small improvements or upgrades made to existing products, services, processes, or methods; usually changes aim at improving an existing product's development efficiency, productivity and competitive differentiation such as changes in films for the modified atmosphere packaging (MAP) [69] or the recovery and reuse of industrial by-products from other firms [70]. These attributes are, of course, relative, and can change during the time or depending on one's perspective. In the papers analyzed, 51 innovations were identified as being radical and 52 as incremental (see again Appendix D); hence, the share among radical and incremental innovation is approximately the same. Five cases in the non-classified column typically refer to literature reviews or theoretical papers. In Table 6 the resulting classification is shown. 
Table 6. The novelty of Innovations (N.C. = non-classified).

\begin{tabular}{cccc}
\hline Type of Innovation & Incremental & Radical & N.C. \\
\hline Product Innovation & 9 & 7 & 3 \\
Process Innovation & 22 & 21 & 0 \\
Organizational Innovation & 17 & 5 & 1 \\
Marketing Innovation & 1 & 0 & 1 \\
Technological Innovation & 3 & 16 & 0 \\
Resource Allocation Innovation & 0 & 2 & 0 \\
Total & 52 & 51 & 5 \\
\hline
\end{tabular}

The last innovation aspect considered is the perspective: the performance of supply chain innovation can be measured through three aspects of sustainability, including economic, environmental, and social aspects [71,72]. Table 7 shows the results of this classification.

Apart from articles in which sustainability is treated in general without a particular perspective highlighted, the most common aspect is, of course, purely economic. This is not surprising, as it is well known that the main aim of a company is profit and, traditionally, economical approaches dominate the literature on supply chain dynamics [73].

Table 7. The dimensions of Innovations (N.C. = non-classified). Note: the results of the previous review are reported in brackets.

\begin{tabular}{cc}
\hline Dimension & Articles \\
\hline Economic & $24(72)$ \\
Environmental & $8(-)$ \\
Social & $5(-)$ \\
Economic + Environmental + Social & $25(-)$ \\
Economic + Environmental & $11(16)$ \\
Economic + Social & $2(3)$ \\
Environmental + Social & $3(-)$ \\
Sustainability (in general) & $33(10)$ \\
N.C. & $11(6)$ \\
\hline
\end{tabular}

Finally, the most common theory and models applied in the 122 articles were identified. A total of 48 theories was recorded. One of the most popular is the Resource-Based Theory (RBT), found in seven articles, used to determine the strategic resources with the potential to deliver a competitive advantage to the firm; the resource-based view of the firm argues that firms use collaborative governance forms to access knowledge, resources, and technologies of other firms [74,75]. Multi-criteria Decision Analysis (MCDA) is also a widespread decision support tool used in four papers, which aids decision makers in determining the degree in which multiple alternatives (i.e., initiatives) perform across a set of relevant criteria in the pursuit of achieving some objective [76]. Relationship theory and the triple bottom line concept are popular as well. Last but not less important is the Life Cycle Management, with its implementation through the Life Cycle Assessment observed in eleven papers, a methodology used to evaluate the environmental impact of a product, process, or activity throughout its entire lifecycle. Appendix $\mathrm{E}$ lists the theories and models identified, with the relating definitions and references.

\section{Discussion and Conclusions}

This paper shows the results from a systematic literature review of the recent literature on SSCI, which is gaining increasing attention from both academics and researchers. This work is the continuum of a previous analysis focusing on a time span of nineteen years (from 1996 to 2014) and focused on the following three years (from 2015 to 2017). Findings and evidence were highlighted in each section, together with the main difference with the previous review. 
The first part of the analysis deals with some descriptive aspects of the 122 papers reviewed. The papers have been classified according to the year of publication, i.e., 2015, 2016 or 2017, showing an upward trend of literature, with a peak of studies published in 2017. The journals that published most of the studies are the Journal of Cleaner Production and Sustainability, with 29 and 17 publications out of 122, respectively; empirical surveys and case studies emerged as the most common research methodologies, covering $68.9 \%$ of the papers reviewed. The manufacturing industry and the agriculture sector are instead the most investigated industry fields ( $55.7 \%$ of the total articles), despite it has not being possible to identify a specific field in many cases $(21.3 \%)$; the most productive countries in terms of the number of articles published are Italy (19 papers), China (15), Brazil (8), and The Netherlands (8).

As far as the thematic analysis is concerned, the key themes of the innovation process were first identified: $34.4 \%$ of articles cover pre-innovation themes, i.e., barriers, obstacles, or motivation to sustainable innovation; $41.8 \%$ of articles deal with innovation themes, that is mainly to say innovation implementation; finally, the remaining $16.4 \%$ is concerned post-innovation issues, such as final assessments and considerations on innovation implementation. In the 122 articles, 108 different types of innovation were identified, most of which are process innovation $(40 \%)$, organization innovation $(21.2 \%)$, product innovation $(17.6 \%)$, and technological innovation $(17.6 \%)$, in line with the results by Gao et al. [24]. This outcome is probably due to the collaborative activities carried out in the SC enhancing (or creating) new product functions and improving the process efficiency and effectiveness. Marketing innovation (1.8\%) and resource allocation innovation (1.8\%) follow. Conversely, innovations are almost equally distributed among incremental and radical. Looking at the sustainability perspectives, most of the innovations focused on economic aspects (approximately $20 \%$ of the total number of articles), while the purely environmental and social ones received less attention (respectively $6.6 \%$ and $4.1 \%$ ). Nonetheless, compared to Gao et al., we found a significantly lower number of papers that focused exclusively on the economic aspects of sustainability (24 vs. 72); this is consonant with the increased awareness about the social and environmental concerns. The last parameter highlighted from the papers reviewed is the set of most common theories and models used to evaluate SSCI, i.e., the Resource-Based Theory, Multi-Criteria Decision Analysis, and Life Cycle Management.

As with any review, this paper does not present new research results per se; rather, its contribution comes from consolidating existing information from many recent studies on SSCI. Moreover, it is the logical prosecution of the review by Gao et al. [24] and complements it. Nonetheless, looking back at the research question of this study, i.e., how research in the field of SSCI is evolving, some trends can be delineated and some avenues for research can be identified.

As far as the trends of the thematic aspect are concerned, compared to the results of the previous review, it is curious to note that the innovation phase was the less developed part in Gao et al.'s paper, argued in just 12 articles out of 107. On the contrary, from 2015 to 2017, it has become the most widely investigated phase (51 papers); the reason for this may be that sustainable innovation is a relatively new subject, thus, at the beginning, barriers and potential obstacles were firstly inspected (in fact, 51 papers of the previous review focused on the pre-innovation phase). In recent years, researchers have gone straight to the heart of the matter and numerous firms have adopted innovation with due regard to the environment and society; hence, the focus has shifted on the innovation phase. The evolution of the different types of innovation is approximately steady, with the only exception being product innovation, for which attention seems to have decreased. Several organizational innovations were recorded, and they gained attention and importance in the last three years, satisfying what Roscoe et al. [5] wished for: more organizational innovations leading to improvements in working conditions through increased visibility of the supply chain, derived through greater stability and, therefore, knowledge and information sharing. Despite that, there is no research exploring how supply chain collaboration (as already mentioned considered as organizational innovation) can improve social sustainability: future directions for research thus include how to improve employee health and working environments, how to decrease child labor usage in developing countries, and how to protect 
female workers' benefits [44]. Concerning the novelty of these innovations, Gao et al. found a different result: 40 radical innovations vs. 23 incremental innovations. The reason for this may simply be the reference years. Indeed, the previous review started with the analysis of the faraway 1996, the moment that sustainable innovations began their evolution. Therefore, the first manifestations were, inevitably, completely new in nature, and therefore radical. Since the concept of "radical" changes over time and, at present, we are facing an advanced stage, what at the beginning could be considered as radical now becomes incremental, and this explains why incremental innovations are now like radical ones. Anyway, we must not forget that "the process of innovation is, of course, never-ending" [77]. The last aspect deserving attention is that, compared to the previous review, we found a significantly lower number of papers that focused exclusively on the economic aspects ( $24 \mathrm{vs.} 72$ ) of sustainability; this is consonant with the increased awareness on social and environmental themes. In fact, we also found 13 articles in which the unique main aspect analyzed is either the environmental or the social ones, and 3 papers where these aspects are taken together. These papers are also the first examples of studies where the economic aspect has not prevailed and suggest increased attention against the environmental and society and of a spread of the innovation and sustainability subject.

From a scientific point of view, the results of this review may be summarized in a framework, depicted in Figure 8, showing the main topics emerged from the analysis of the literature previously discussed. These topics may be grouped into four dimensions, labeled in the framework as:

- Why not/Why, including the barriers and obstacles ("why not") that hinder, as well as the motivations ("why") that lead to the implementation of a sustainable innovation. This dimension includes the aspects that emerged with reference to the pre-innovation phase.

- How, that is, how the innovation process is developed in its main phases (pre-innovation, innovation, and post-innovation). This dimension includes the main features and trends emerged with reference to the innovation implementation phase, as well as the steps undertaken in the post-innovation phase.

- What, that is, the main innovation according to their degree of novelty (radical vs. incremental) or to their type (i.e., product, process, organizational, marketing, technological, resource allocation).

- Sustainability, reflecting the dimensions by which the different innovations are measured, i.e., economic, environmental, social or mixed, since the original aim is to investigate the linkage between innovation and its role in sustainable development. 


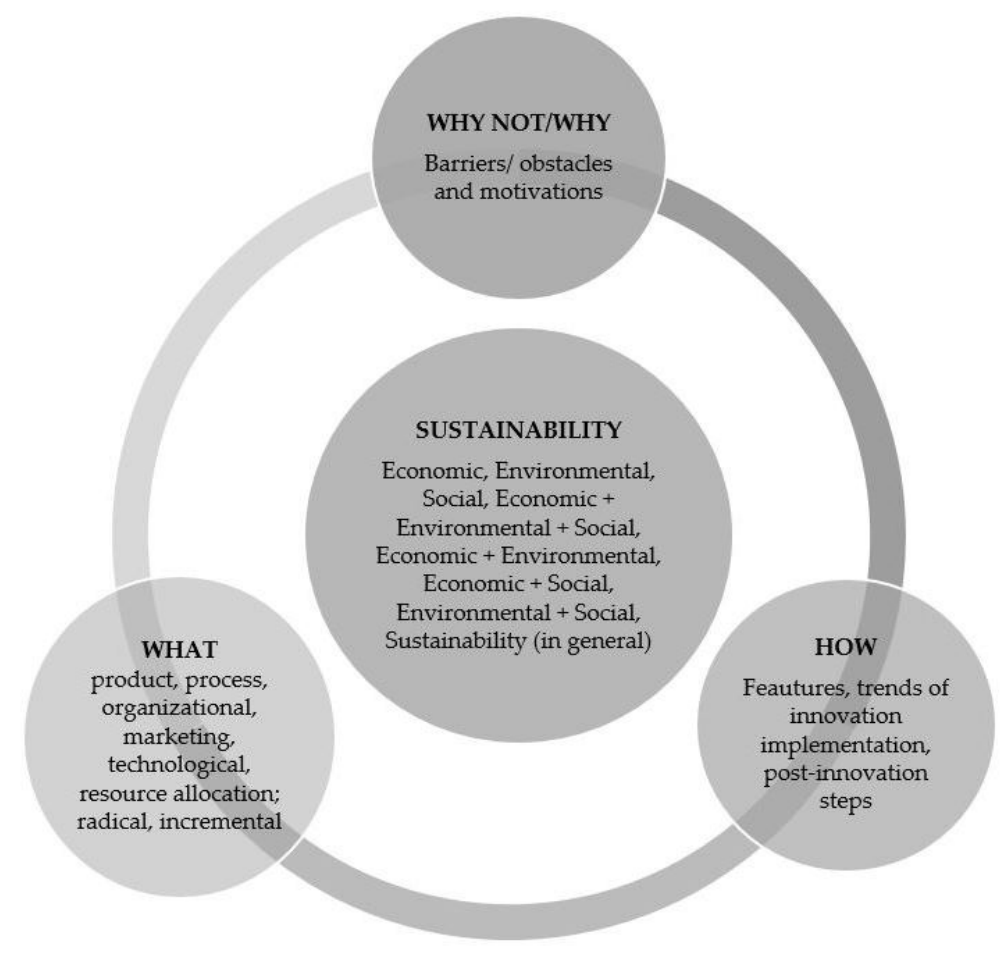

Figure 8. The framework resulted from a systematic literature review.

This conceptual framework is a contribution to the request in the literature [78] to formulate concepts and theories for analyzing and understanding how the implementation process of sustainability in supply networks occurs [72]. In particular, it is focused on the innovation aspect, which needs to be integrated in order to fill the gaps of the previous frameworks in this field as Van Bommel highlighted.

Authors could benefit from this model, which could be used as the starting point to carry out a set of case studies, interviews, and other kinds of empirical research on the SSCI topic. Empirical research will allow us to gain further insights on the topic and to validate the framework itself. To this end, the results of this review suggest that case studies should preferably target less developed countries, which have been significantly less explored in the literature. Regarding this last point, it should not be forgotten, however, that the geographical distribution is quite heterogeneous; accordingly, the intervention and the collaboration of wealthier states is at the same time essential.

Furthermore, the thematic analysis showed that purely environmental and social dimensions of SSCI, despite their timidly start to gain attention, are less inspected and overpowered by the economic one; more should be done in this direction. The lack of research in many industrial sectors emerges as well, such as the construction industry, which has been accused of causing several environmental problems [79] or the mining and quarrying sector, impacting the environment with air pollution and waste disposal [80]. We suggest deeper research in these fields.

Marketing innovation should deserve particular attention in the authors' opinion: in fact, there is a growing number of customers looking for green products [81] and they tend to reward the most virtuous companies in terms of sustainable achievements; in this sense, marketing innovations could attract clients and become a strength for both environment and economic reasons. Good recommendations in this regard are provided by Dangelico and Vocalelli [66].

Moreover, it was noted by analyzing the literature that the role of consumers in the supply chain as a driver to sustainable innovation has not yet been properly addressed: sustainable consumption should be studied systematically. This could be an interesting insight for future research activities.

The study has, of course, some limitations. Firstly, in the review, we have only considered papers that are written in English and published in international journals only. Obviously, this 
approach excludes papers written in other languages as well as other types of publications, such as conference papers, and, therefore, could lead to some loss of information. Secondly, the keywords' choice could also lead to selecting some papers but excluding other ones, where the authors have used slightly different keywords. Finally, the findings in the literature review strongly depend on the reviewers' experience and educational background, and some attributes can be considered as a matter of opinion [24].

Author Contributions: L.T. collected the material and carried out the analyses on the studies reviewed. E.B. acted as the coordinator of this study and reviewed the studies collected from the sustainability perspective. B.B. reviewed the studies collected from the innovation perspective. The paper was assembled by all of the authors.

Funding: This research was supported by the research Grant No. D92I15000210008 (project code RBSI14L97M), called "ESCALATE-Economic and Environmental Sustainability of Supply Chain and Logistics with Advanced Technologies", funded by the Italian Ministry of University and Research under the SIR (Scientific Independence of young Researchers) 2014 program (decree of 23 January 2014, No. 197) and awarded to the corresponding author (E.B.).

Conflicts of Interest: The authors declare no conflict of interest. The founding sponsors had no role in the design of the study; in the collection, analyses or interpretation of data; in the writing of the manuscript; nor in the decision to publish the results

\section{Appendix A}

Table A1. The classifications of the studies reviewed per methodology applied.

\begin{tabular}{ll}
\hline Methodology Applied & References \\
\hline Empirical Surveys & {$[12,30,33,37,40,48,50,53,63,65,69,82-126]$} \\
Case Studies & {$[13,15,16,49,51,62,127-148]$} \\
Theoretical and Conceptual Papers & {$[46,54,64,67,68,149-162]$} \\
Modeling Papers & {$[45,70,76,163-169]$} \\
Literature Reviews & {$[24,27,29,39,44,66,170-172]$} \\
\hline
\end{tabular}

\section{Appendix B}

Table A2. The classification of the studies reviewed per industrial sector.

\begin{tabular}{ll}
\hline Industrial Sector & References \\
\hline A-Agriculture, Forestry and Fishing & {$[62,63,67,71,93,96,97,106,116,125,126,128,129,131,135,138$,} \\
& $139,142,144,146,152,158,166,170]$ \\
\hline B-Mining and Quarrying & {$[49,103,148]$} \\
\hline \multirow{2}{*}{ C-Manufacturing } & {$[13,15,28,33,37,48,50,64,69,70,82,86,88-90,92,94,95,99,101$,} \\
& $105,107,109,111-113,115,117-121,124,132-134,136,140$, \\
\hline D-Electricity, Gas, Steam, and Air & $153,155,163,165,167,168]$ \\
Conditioning Supply & {$[156,157]$} \\
\hline F-Construction & {$[53,130,145]$} \\
\hline H-Transportation and Storage & {$[12,143,162,171,172]$} \\
\hline S-Service Activities & {$[51,54,137,169]$} \\
\hline X-No Specific Sector & {$[24,27,29,39,44,45,66,68,76,84,85,98,100,102,104,122,123$,} \\
\hline V-Multiple Sector & $147,149,150,153,154,159-161,164]$ \\
\hline
\end{tabular}




\section{Appendix C}

Table A3. The references for each phase of innovation related to their novelty (N.A. = not available).

\begin{tabular}{ll}
\hline Phase & References \\
\hline \multirow{2}{*}{ Pre-Innovation } & {$[12,39,53,54,62,63,67,68,70,76,82,85,89-91,96,102,105,114,115,126,131$,} \\
& $132,144,147,149,150,152-158,160-164,167-169]$ \\
\hline \multirow{2}{*}{ Innovation } & {$[16,30,33,37,40,45,48,49,64,65,69,83,84,87,93,95,97,100,101,105-113,116-$} \\
& $118,120,121,123-125,127-130,134,137,138,141-143,145,146,151,159,165]$ \\
\hline Post-Innovation & {$[13,46,50,51,86,88,92,94,99,104,119,122,130,133,135,136,139,140,148,166]$} \\
\hline N.A. & {$[24,27,29,44,66,98,170-172]$} \\
\hline
\end{tabular}

\section{Appendix D}

Table A4. The references for each type of innovation related to its novelty (N.A. = not available).

\begin{tabular}{|c|c|c|c|}
\hline $\begin{array}{l}\text { Type of } \\
\text { Innovation }\end{array}$ & Incremental & Radical & N.A. \\
\hline $\begin{array}{l}\text { Product } \\
\text { Innovation }\end{array}$ & {$[16,69,88,96,99,108,132,136,145]$} & {$[92,132,136,152,159,168]$} & $\begin{array}{l}{[29,114,} \\
161]\end{array}$ \\
\hline $\begin{array}{l}\text { Process } \\
\text { Innovation }\end{array}$ & $\begin{array}{l}{[12,16,30,62,64,65,70,86,92,96,101,} \\
126,128]\end{array}$ & $\begin{array}{l}{[12,49,67,68,76,91,92,125,127,129,} \\
132,134,136,140,153,159,166,167]\end{array}$ & / \\
\hline $\begin{array}{l}\text { Organizational } \\
\text { Innovation }\end{array}$ & $\begin{array}{l}{[15,16,33,39,45,46,49,62,110,118,} \\
136,138,146,147,155,159,165]\end{array}$ & {$[48,51,133,135,137]$} & {$[44]$} \\
\hline $\begin{array}{l}\text { Marketing } \\
\text { Innovation }\end{array}$ & [150] & / & {$[66]$} \\
\hline $\begin{array}{l}\text { Technological } \\
\text { Innovation }\end{array}$ & {$[92,96,136]$} & {$[53,54,68,95,96,130,136,172]$} & / \\
\hline $\begin{array}{l}\text { Resource } \\
\text { Allocation } \\
\text { Innovation }\end{array}$ & / & {$[62,63]$} & / \\
\hline
\end{tabular}




\section{Appendix E}

Table A5. The theories and models identified in the study and references.

\begin{tabular}{|c|c|c|}
\hline Model/Theory & Definition & References \\
\hline Absorptive Capacity & The firm's ability to recognize the value of new information, assimilate it, and apply it to commercial ends. & {$[145,148]$} \\
\hline $\begin{array}{l}\text { AMO-Ability Motivation } \\
\text { Opportunity Theory }\end{array}$ & The employee's ability, desire, and opportunity to make a contribution to job performance. & [30] \\
\hline Analytic Network Process & $\begin{array}{l}\text { ANP is an evolution of the analytic hierarchy process (AHP) used in multi-criteria decision analyses, which } \\
\text { structure a decision problem into a network with a goal, decision criteria, and alternatives. }\end{array}$ & {$[134,160]$} \\
\hline BSC_-Balanced Scorecard & $\begin{array}{l}\text { BSC is a strategy performance management tool-A semi-standard structured report, that can be used by } \\
\text { managers to keep track of the execution of activities by the staff within their control and to monitor the } \\
\text { consequences arising from these actions. }\end{array}$ & {$[154,160]$} \\
\hline Benchmarking & $\begin{array}{l}\text { Benchmarking is comparing one's business processes and performance metrics to industry bests and the } \\
\text { best practices from other companies }\end{array}$ & {$[15,132]$} \\
\hline Business Ethics & $\begin{array}{l}\text { Business ethics (or corporate ethics) is a form of applied ethics or professional ethics, that examines ethical } \\
\text { principles and moral or ethical problems that can arise in a business environment. }\end{array}$ & [33] \\
\hline Competitive Theory & $\begin{array}{l}\text { Competitive theory suggests that states and businesses should pursue policies that create high-quality } \\
\text { goods to sell at high prices in the market. }\end{array}$ & {$[48,84]$} \\
\hline Complexity Theory & $\begin{array}{l}\text { Complexity theory is the use of the study of complexity systems in the field of strategic management and } \\
\text { organizational studies. It is an interdisciplinary theory that grew out of systems theory in the 1960s. }\end{array}$ & [103] \\
\hline Contingency Theory & $\begin{array}{l}\text { A contingency theory is an organizational theory that claims that there is no best way to organize a } \\
\text { corporation, to lead a company, or to make decisions. Instead, the optimal course of action is contingent } \\
\text { (dependent) upon the internal and external situation. }\end{array}$ & {$[27,87,148]$} \\
\hline $\begin{array}{l}\text { Contractual Coordination } \\
\text { Mechanisms }\end{array}$ & $\begin{array}{l}\text { A set of partner-specific communication, routines, liaison and integration roles, interfirm authorities, group } \\
\text { problem solving, planning, and various forms and degrees of property-right sharing. }\end{array}$ & [46] \\
\hline Decision Theory & The study of the reasoning underlying an agent's choices. & [86] \\
\hline $\begin{array}{l}\text { DTPB-Decomposed Theory of } \\
\text { Planned Behaviour }\end{array}$ & $\begin{array}{l}\text { A theory for studying adoption processes. It decomposes the three main antecedents of behavioral intention } \\
\text { of the Theory of Planned Behaviour into a set of salient beliefs based on the Innovation Diffusion Theory } \\
\text { and the Technology Acceptance Model. }\end{array}$ & [90] \\
\hline Delphi Method & $\begin{array}{l}\text { A structured communication technique or method, originally developed as a systematic, interactive } \\
\text { forecasting method which relies on a panel of experts. }\end{array}$ & {$[12,93]$} \\
\hline
\end{tabular}


Table A5. Cont.

\begin{tabular}{|c|c|c|}
\hline Model/Theory & Definition & References \\
\hline DEMATEL Method & $\begin{array}{l}\text { A decision-making tool that helps in gathering group knowledge, visualizing the causal relationships of the } \\
\text { criteria, and indicates the degree of influence through a cause-effect diagram. }\end{array}$ & {$[90,144]$} \\
\hline Dynamic Capabilities Theory & $\begin{array}{l}\text { In organizational theory, dynamic capability is the capability of an organization to purposefully adapt an } \\
\text { organization's resource base. }\end{array}$ & {$[90]$} \\
\hline Eco-efficiency Concept & $\begin{array}{l}\text { Eco-efficiency is a quantitative management tool that enables the consideration of the life cycle } \\
\text { environmental impacts of a product system alongside its product system value to a stakeholder. }\end{array}$ & {$[115,128]$} \\
\hline Ecological Modernization Theory & $\begin{array}{l}\text { A school of thought in the social sciences that argues that the economy benefits from moves towards } \\
\text { environmentalism. }\end{array}$ & [137] \\
\hline Emergy Assessment & $\begin{array}{l}\text { The evaluation of the "emergy" used in the work processes that generate a product or service in units of one } \\
\text { type of energy. By definition, "emergy" is the amount of energy of one form (usually solar) that is required, } \\
\text { directly or indirectly, to provide a given flow or storage of energy or matter. }\end{array}$ & [62] \\
\hline Fuzzy Analytic Hierarchy Process & A decision-making method for multiple criteria decision-making in a fuzzy environment. & [111] \\
\hline Fuzzy Theory & $\begin{array}{l}\text { A form of many-valued logic in which the truth values of variables may be any real number between } 0 \text { and } \\
\text { 1. It is employed to handle the concept of partial truths, where the truth value may range between } \\
\text { completely true and completely false. }\end{array}$ & {$[107,131]$} \\
\hline Games Theory & $\begin{array}{l}\text { A branch of mathematics concerned with the analysis of strategies for dealing with competitive situations } \\
\text { where the outcome of a participant's choice of action depends critically on the actions of other participants. }\end{array}$ & {$[100,155,165,168]$} \\
\hline Grounded Theory & $\begin{array}{l}\text { A systematic methodology in the social sciences involving the construction of theory through methodical } \\
\text { gathering and the analysis of data. }\end{array}$ & [148] \\
\hline $\begin{array}{l}\text { IDT-Innovation Diffusion } \\
\text { Theory }\end{array}$ & $\begin{array}{l}\text { An established innovation theory focusing on understanding how, why and at what rate innovative ideas } \\
\text { and technologies spread in a social system. }\end{array}$ & {$[90]$} \\
\hline $\begin{array}{l}\text { Importance-Performance } \\
\text { Analysis }\end{array}$ & $\begin{array}{l}\text { A popular managerial tool for organizational performance development. This technique helps customer } \\
\text { satisfaction understanding, as well as detecting and placing priority on those services/products for which } \\
\text { improvement is necessary. }\end{array}$ & [134] \\
\hline Input-Output Analysis & $\begin{array}{l}\text { Macroeconomic analysis based on the interdependencies between economic sectors or industries used for } \\
\text { modelling the generation of wastes along supply chains. }\end{array}$ & {$[120,147]$} \\
\hline Institutional Theory & $\begin{array}{l}\text { A theory according to which institutional environments place pressure on organizations to appear } \\
\text { legitimate and conform to prevailing norms used to adequately respond to changing conditions of the } \\
\text { regulatory environment. }\end{array}$ & {$[45,90,103,116,138]$} \\
\hline $\begin{array}{l}\text { ISM-Interpretive Structural } \\
\text { Modeling Approach }\end{array}$ & A method that identifies and summarizes the relationships among specific variables. & {$[85,115,144]$} \\
\hline
\end{tabular}


Table A5. Cont.

\begin{tabular}{|c|c|c|}
\hline Learning Theory & $\begin{array}{l}\text { Definition } \\
\text { A theory used to highlight the importance of acquiring knowledge through inter-organizational } \\
\text { relationships to promote cleaner production methods and improve environmental performance in the } \\
\text { context of inter-organizational networks. }\end{array}$ & References \\
\hline Life Cycle Thinking & A technique to assess environmental impacts in the whole supply chain & $\begin{array}{l}{[62,76,92,100,101,128,} \\
129,140,142,147,158]\end{array}$ \\
\hline Monte Carlo Method & $\begin{array}{l}\text { A Computation intensive forecasting technique used to estimate costs associated with utilizing the available } \\
\text { woody biomass for energetic use. }\end{array}$ & [126] \\
\hline $\begin{array}{l}\text { MCDA-Multi-Criteria Decision } \\
\text { Analysis }\end{array}$ & $\begin{array}{l}\text { A sub-discipline of operations research that explicitly evaluates multiple conflicting criteria in decision } \\
\text { making; it is used to assess sustainability performance. }\end{array}$ & {$[76,90,128,131]$} \\
\hline $\begin{array}{l}\text { MRIO-Multi-Regional } \\
\text { Input-Output Analysis }\end{array}$ & $\begin{array}{l}\text { A method for quantitatively showing the influence that the investment to a specific area affects the } \\
\text { surrounding area analysis; it is used to generate information about socio-economic impacts of biomass } \\
\text { supply chains, such as economic value added, and job creation, directly and indirectly, related to the } \\
\text { activities involved in a system. }\end{array}$ & {$[62]$} \\
\hline $\begin{array}{l}\text { QCA-Qualitative Comparative } \\
\text { Analysis }\end{array}$ & $\begin{array}{l}\text { A data analysis technique for determining which logical conclusions a dataset supports; it is used to study } \\
\text { how factors combine into configurations of institutional and organizational conditions. }\end{array}$ & [116] \\
\hline RVT-Relational View Theory & $\begin{array}{l}\text { A theory based on the formation of inter-organizational relationships in order to acquire knowledge; it is } \\
\text { used to explore the development of sustainable relationships and practices in inter-organizational networks. }\end{array}$ & {$[33,138]$} \\
\hline Reliability Analysis & $\begin{array}{l}\text { An analysis that is used for the description system with some (more than two) levels of performance } \\
\text { (availability, reliability). }\end{array}$ & [163] \\
\hline Resilience Theory & $\begin{array}{l}\text { A multifaceted field of study addressing the strengths that people and systems demonstrate that enable } \\
\text { them to rise above adversity; it is used to understand the complex dynamics that arise from interactions } \\
\text { between human and environmental systems. }\end{array}$ & [149] \\
\hline RBV_-Resource-Based View & $\begin{array}{l}\text { A management device for the assessment of the available amount of a business' strategic assets; it is used to } \\
\text { explain corporate sustainability strategies, sustainability competitive advantage, and sustainable supply } \\
\text { chain management. }\end{array}$ & $\begin{array}{l}{[16,33,40,46,118,137} \\
138]\end{array}$ \\
\hline Risk Management & $\begin{array}{l}\text { The identification, evaluation, and prioritization of risks followed by the coordinated and economical } \\
\text { application of resources to minimize, monitor, and control the probability or impact of unfortunate events } \\
\text { or to maximize the realization of opportunities. }\end{array}$ & [76] \\
\hline Rough Set Theory & $\begin{array}{l}\text { A method for extracting previously unknown data dependencies or rules from relational databases or } \\
\text { decision tables without any preliminary or additional information. }\end{array}$ & [169] \\
\hline
\end{tabular}


Table A5. Cont.

\begin{tabular}{|c|c|c|}
\hline Model/Theory & Definition & References \\
\hline Stakeholders Theory & $\begin{array}{l}\text { A conceptual framework of business ethics and organizational management which addresses moral and } \\
\text { ethical values in the management of a business or other organization. }\end{array}$ & {$[90,109,148,164]$} \\
\hline $\begin{array}{l}\text { SEM-Structural Equation } \\
\text { Modeling }\end{array}$ & $\begin{array}{l}\text { A set of mathematical models, computer algorithms, and statistical methods that fit networks of constructs } \\
\text { to data. }\end{array}$ & {$[111,117,118,135]$} \\
\hline $\begin{array}{l}\text { Supply-Chain Operation } \\
\text { Reference Model }\end{array}$ & $\begin{array}{l}\text { A process reference model that describes the business activities associated with satisfying a customer's } \\
\text { demand; it is used to identify the links and logistics operations in all the stages of the supply chain of } \\
\text { renewable energy management. }\end{array}$ & [102] \\
\hline $\begin{array}{l}\text { System Dynamics Simulation } \\
\text { Analysis }\end{array}$ & $\begin{array}{l}\text { A methodology and mathematical modeling technique to frame, understand, and discuss complex issues } \\
\text { and problems; it is used to demonstrate the rationale of green component procurement collaboration and } \\
\text { how the collaborative system could reduce the risk in the supply line and eventually improve the supply } \\
\text { chain performance. }\end{array}$ & {$[15]$} \\
\hline $\begin{array}{l}\text { TAM-Technology Acceptance } \\
\text { Model }\end{array}$ & An information systems theory that models how users accept and use a technology. & {$[63,90]$} \\
\hline $\begin{array}{l}\text { TPB-Theory of Planned } \\
\text { Behavior }\end{array}$ & $\begin{array}{l}\text { A psychological theory based on the assumption that individuals often behave rationally taking into } \\
\text { account the available information, and implicitly or explicitly taking into account the implications of their } \\
\text { actions. }\end{array}$ & {$[63,67,100]$} \\
\hline TOE Approach & $\begin{array}{l}\text { A framework that identifies three context groups (technological, organizational, and environmental) that } \\
\text { may influence the organizational adoption of an innovation. }\end{array}$ & {$[90]$} \\
\hline Transaction Cost Theory & $\begin{array}{l}\text { A theory accounting for the actual cost of outsourcing production of products or services including } \\
\text { transaction costs, contracting costs, coordination costs, and search costs; it is used to examine the } \\
\text { effectiveness of governance mechanisms in managing buyer-seller relationships with respect to } \\
\text { environmental issues. }\end{array}$ & {$[52,125,138]$} \\
\hline Value Mapping & $\begin{array}{l}\text { An approach for ideation and analysis for sustainable business model innovation involving mapping the } \\
\text { value captured, missed, and destroyed and new opportunities for a range of stakeholders, to assist in the } \\
\text { design of sustainable business models. }\end{array}$ & [164] \\
\hline
\end{tabular}




\section{References}

1. Rajeev, A.; Pati, R.K.; Padhi, S.S.; Govindan, K. Evolution of sustainability in supply chain management: A literature review. J. Clean. Prod. 2017, 162, 299-314. [CrossRef]

2. Hall, J.K.; Daneke, G.A.; Lenox, M.J. Sustainable development and entrepreneurship: Past contributions and future directions. J. Bus. Ventur. 2010, 25, 439-448. [CrossRef]

3. Tang, A.K.Y.; Lai, K.-H.; Cheng, T.C.E. A Multi-research-method approach to studying environmental sustainability in retail operations. Int. J. Prod. Econ. 2016, 171, 394-404. [CrossRef]

4. Klewitz, J.; Hansen, E.G. Sustainability-oriented innovation of SMEs: A systematic review. J. Clean. Prod. 2014, 65, 57-75. [CrossRef]

5. Roscoe, S.; Cousins, P.D.; Lamming, R.C. Developing eco-innovations: A three-stage typology of supply networks. J. Clean. Prod. 2016, 112, 1948-1959. [CrossRef]

6. Aragón-Correa, J.A.; Hurtado-Torres, N.; Sharma, S.; García-Morales, V.J. Environmental strategy and performance in small firms: A resource-based perspective. J. Environ. Manag. 2008, 86, 88-103. [CrossRef] [PubMed]

7. Noci, G.; Verganti, R. Managing 'green' product innovation in small firms. $R$ D Manag. 1999, $29,3-15$. [CrossRef]

8. Roome, N.; Hinnels, M. Environmental factors in the management of new product development: Theoretical framework and some empirical evidence from the white goods industry. Bus. Strateg. Environ. 1993, 2, $12-27$. [CrossRef]

9. Schiederig, T.; Tietze, F.; Herstatt, C. Green innovation in technology and innovation management-An exploratory literature review. $R$ D Manag. 2012, 42, 180-192. [CrossRef]

10. Huber, J. Technological environmental innovations (TEIs) in a chain-analytical and life-cycle-analytical perspective. J. Clean. Prod. 2008, 16, 1980-1986. [CrossRef]

11. Van Hemel, C.; Cramer, J. Barriers and stimuli for ecodesign in SMEs. J. Clean. Prod. 2012, 10, 439-453. [CrossRef]

12. Von der Gracht, H.A.; Darkow, I.-L. Energy-constrained and the low-carbon scenarios for the transportation and logistic industry. Int. J. Logist. Manag. 2016, 27, 142-166. [CrossRef]

13. Koster, M.; Vos, B.; Schroeder, R. Management innovation driving sustainable supply management-Process studies in exemplar MNEs. BRQ Bus. Q. 2017, 20, 240-257. [CrossRef]

14. Srivastava, S.K. Green supply-chain management: A state-of-the-art literature review. Int. J. Manag. Rev. 2007, 9, 53-80. [CrossRef]

15. Yan, M.-R.; Chien, K.-M.; Yang, T.-N. Green component procurement collaboration for improving supply chain management in the high technology industries: A case study from the systems perspective. Sustainability 2016, 8, 105. [CrossRef]

16. Lopes de Sousa Jabbour, A.B.; Cortegoso de Oliveira Frascarelli, F.; Chiappetta Jabbour, C.J. Green supply chain management and firms' performance: Understanding potential relationship and the role of green sourcing and some other green practices. Resour. Conserv. Recycl. 2015, 104, 366-374. [CrossRef]

17. Turki, S.; Rezg, N. Impact of the Quality of Returned-Used Products on the Optimal Design of a Manufacturing/Remanufacturing System under Carbon Emissions Constraints. Sustainability 2018, 10, 3197. [CrossRef]

18. Koplin, J.; Seuring, S.; Mesterham, M. Incorporating sustainability into supply management in the automotive industry- the case of the Volkswagen AG. J. Clean. Prod. 2007, 15, 1053-1062. [CrossRef]

19. Touboulic, A.; Chicksand, D.; Walker, H. Managing imbalanced supply chain relationships for sustainability: A power perspective. Decis. Sci. 2014, 45, 577-619. [CrossRef]

20. Bottani, E.; Casella, G. Minimization OD the environmental emissions of closed-loop supply chains: A case study of returnable transport assets management. Sustainability 2018, 10, 329. [CrossRef]

21. Genovese, A.; Acquaye, A.A.; Figueroa, A.; Lenny Koh, S.C. Sustainable supply chain management and the transition towards a circular economy: Evidence and some applications. Omega 2017, 66, 344-357. [CrossRef]

22. French, M.L.; La Forge, R.L. Closed-loop supply chains in process industries: An empirical study of producer re-use issues. J. Oper. Manag. 2006, 24, 271-286. [CrossRef]

23. Son, D.; Kim, S.; Park, H.; Jeong, B. Closed-Loop Supply Chain Planning Model of Rare Metals. Sustainability 2018, 10, 1061. [CrossRef] 
24. Gao, D.; Xu, Z.; Ruan, Y.Z.; Lu, H. From a systematic literature review to integrated definition for sustainable supply chain innovation (SSCI). J. Clean. Prod. 2017, 142, 1518-1538. [CrossRef]

25. Damanpour, F. Organizational innovation: A meta-analysis of effects of determinants and moderators. Acad. Manag. J. 1991, 34, 555-590. [CrossRef]

26. Teipal, T.; Garg, R.K.; Sachdeva, A. Trust among supply chain partners: A review. Meas. Bus. Excell. 2013, 17, 51-71. [CrossRef]

27. Khalid, R.U.; Seuring, S.; Beske, P.; Land, A.; Yawar, S.A.; Wagner, R. Putting sustainable supply chain management into base of the pyramid research. Supply Chain Manag. 2015, 20, 681-696. [CrossRef]

28. Mayring, P. Qualitative Content Analysis, 8th ed.; Beltz Verlag: Weinheim, Germany, 2003.

29. Thomé, A.M.T.; Scavarda, A.; Ceryno, P.S.; Remmen, A. Sustainable new product development: A longitudinal review. Clean Technol. Environ. Policy 2016, 18, 2195-2208. [CrossRef]

30. Rajiani, I.; Musa, H.; Hardjono, B. Ability, motivation and opportunity as determinants of green human resources management innovation. Res. J. Bus. Manag. 2016, 10, 51-57. [CrossRef]

31. Seuring, S.; Müller, M. From a literature review to a conceptual framework for sustainable supply chain management. J. Clean. Prod. 2008, 16, 1699-1710. [CrossRef]

32. Statistic Division, Department of Economic and Social Affairs. International Standard Industrial Classification of All Economic Activities; Statistic Division, Department of Economic and Social Affairs: New York, NY, USA, 2008.

33. Gualandris, J.; Kalchschmidt, M. Developing environmental and social performance: The role of suppliers' sustainability and buyer-supplier trust. Int. J. Prod. Res. 2016, 54, 2470-2486. [CrossRef]

34. Hansen, E.G.; Grosse-Dunker, F.; Reichvald, R. Sustainability innovation cube-A framework to evaluate sustainability-oriented innovations. Int. J. Innov. Manag. 2009, 13, 683-713. [CrossRef]

35. R\&D Magazine (Supplement). Global Funding of Research and Development Overview; R\&D Magazine: Rockaway, NJ, USA, 2017.

36. Global Sustainable Investment Alliance. Global Sustainable Investment Review. 2016. Available online: http:/ / www.gsi-alliance.org (accessed on 18 June 2018).

37. Kucht Campos, J.; Straube, F.; Wutke, S.; Alcântara Cardoso, P. Creating value by sustainable manufacturing and supply chain management practices-A cross-country comparison. Procedia Manuf. 2017, 8, 686-690. [CrossRef]

38. Sirilli, G. Innovazione Tecnologica. Istituto della Enciclopedia Italiana fondata da Giovanni Treccani. Voce Encicl. Novecento 2004, XIII, 44-53.

39. Govindan, K.; Seuring, S.; Zhu, Q.; Azevedo, S.G. Accelerating the transition towards sustainability dynamics into supply chain relationship management and governance structures. J. Clean. Prod. 2016, 112, 1813-1823. [CrossRef]

40. Bhardwaj, B.R. Role of green policy on sustainable supply chain management-A model for implementing corporate social responsibility (CSR). Benchmarking Int. J. 2016, 23, 456-468. [CrossRef]

41. Chiappetta Jabbour, C.J.; Jugend, D.; Lopes de Sousa Jabbour, A.B.; Govindan, K.; Kannan, D.; Leal Filho, W. "There is no carnival without samba": Revealing barriers hampering biodiversity-based R\&D and eco-design in Brazil. J. Environ. Manag. 2018, 206, 236-245. [CrossRef]

42. Taneja, S.; Golden Pryor, M.; Hayek, M. Leaping innovation barriers to small business longevity. J. Bus. Strateg. 2016, 37, 44-51. [CrossRef]

43. Luthra, S.; Kumar, V.; Kumar, S.; Haleem, A. Barriers to implement green supply chain management in automobile industry using interpretive structural modeling technique: An Indian perspective. J. Ind. Eng. Manag. 2011, 4, 231-257. [CrossRef]

44. Chen, L.; Zhao, X.; Tang, O.; Price, L.; Zhang, S.; Zhu, W. Supply chain collaboration for sustainability: A literature review and future research agenda. Int. J. Prod. Econ. 2017, 194, 73-87. [CrossRef]

45. Yenipazarli, A. To collaborate or not to collaborate: Prompting upstream eco-efficient innovation in a supply chain. Eur. J. Oper. Res. 2017, 260, 571-587. [CrossRef]

46. Niesten, E.; Jolink, A.; Lopes de Sousa Jabbour, A.B.; Chappin, M.; Lozano, R. Sustainable collaboration: The impact of governance and institutions on sustainable performance. J. Clean. Prod. 2017, 155, 1-6. [CrossRef]

47. Zeng, H.; Chen, X.; Xiao, X.; Zhou, Z. Institutional pressures, sustainable supply chain management, and circular economy capability: Empirical evidence from Chinese eco-industrial park firms. J. Clean. Prod. 2017, 155, 54-65. [CrossRef] 
48. Berti, G.; Mulligan, C. Competitiveness of small farms and innovative food supply chains: The role of food hubs in creating sustainable regional and local food systems. Sustainability 2016, 8, 616. [CrossRef]

49. Kate, J.T.; Teunter, R.; Kusumastuti, R.D.; van Donk, D.P. Bio-diesel production using mobile processing units: A case in Indonesia. Agric. Syst. 2017, 152, 121-130. [CrossRef]

50. Wu, G.-C. Effects of Socially Responsible Supplier Development and Sustainability-Oriented Innovation on Sustainable Development: Empirical Evidence from SMEs. Corp. Soc. Responsib. Environ. Manag. 2017, 24, 661-675. [CrossRef]

51. Picciotti, A. Towards sustainability: The innovation paths of social enterprise. Ann. Public Coop. Econ. 2017, 88, 233-256. [CrossRef]

52. Schumpeter, J.A. The Theory of Economic Development: An Inquiry into Profits, Capital, Credit, Interest, and the Business Cycle; Social Science Electronic Publishing: New York, NY, USA, 1934.

53. Iacovidou, E.; Purnell, P.; Lim, M.K. The use of smart technologies in enabling construction components reuse: A viable method or a problem creating solution? J. Environ. Manag. 2016, 216, 214-223. [CrossRef] [PubMed]

54. Gallico, D. E-learning sustainability: Creation of a new platform for designing new community identity through lifelong learning. World Rev. Sci. Technol. Sustain. Dev. 2015, 12, 67-76. [CrossRef]

55. Clarysse, B.; Van Dierdonck, R.; Gabriels, W.; Lambrechts, J.; Uytterhaegen, M. Strategische Verschillen Tussen Innovative KMOs: Een Kijkje in de Zwarte Doos; Publication No. 5; IWT: Brussels, Belgium, 1998.

56. Bigliardi, B.; Dormio, A.I. An empirical investigation of innovation determinants in food machinery enterprises. Eur. J. Innov. Manag. 2009, 12, 223-242. [CrossRef]

57. Damanpour, F.; Evan, W.M. Organizational innovation and performance: The problem of "Organizational Lag". Adm. Sci. Q. 1984, 29, 392-409. [CrossRef]

58. Deshpandé, R.; Farley, J.U.; Webster, F.E. Corporate culture, customer orientation and innovativeness in Japanese firms: A quadrad analysis. J. Mark. 1993, 57, 23-37. [CrossRef]

59. Hult, G.T.M.; Hurley, R.F. Innovation, market orientation, and organizational learning: An integration and empirical examination. J. Mark. 1998, 62, 42-54.

60. Rogers, E.M. Diffusion of Innovations; Free Press of Glencoe: New York, NY, USA, 1962.

61. Hazen, B.T.; Overstreet, R.E.; Cegielski, C.G. Supply chain innovation diffusion: Going beyond adoption. Int. J. Logist. Manag. 2012, 23, 119-134. [CrossRef]

62. Perrin, A.; Wohlfahrt, J.; Morandi, F.; Østergård, H.; Flatberg, T.; De La Rua, C.; Gabrielle, B. Integrated design and sustainable assessment of innovative biomass supply chains: A case-study on miscanthus in France. Appl. Energy 2017, 204, 66-77. [CrossRef]

63. Naspetti, S.; Mandolesi, S.; Buysse, J.; Latvala, T.; Nicholas, P.; Padel, S.; Zanoli, R. Determinants of the acceptance of sustainable production strategies among dairy farmers: Development and testing of a modified technology acceptance model. Sustainability 2017, 9, 1805. [CrossRef]

64. Kircher, M. Sustainability of biofuels and renewable chemicals production from biomass. Curr. Opin. Chem. Biol. 2015, 29, 26-31. [CrossRef] [PubMed]

65. Tencati, A.; Pogutz, S.; Mode, B.; Brambilla, M.; Cacia, C. Prevention policies addressing packaging and packaging waste: Some emerging trends. Waste Manag. 2016, 56, 35-45. [CrossRef] [PubMed]

66. Dangelico, R.M.; Vocalelli, D. "Green Marketing": An analysis of definitions, strategy steps, and tools through a systematic review of the literature. J. Clean. Prod. 2017, 165, 1263-1279. [CrossRef]

67. Dos Santos, M.J.P.L. Smart cities and urban areas-Aquaponics as innovative urban agriculture. Urban For. Urban Green. 2016, 20, 402-406. [CrossRef]

68. Despeisse, M.; Baumers, M.; Brown, P.; Charnely, F.; Ford, S.J.; Garmulewicz, A.; Knowles, S.; Minshall, T.H.W.; Mortara, L.; Reed-Tsochas, F.P.; et al. Unlocking value for a circular economy through 3D printing: A research agenda. Technol. Forecast. Soc. 2017, 115, 75-84. [CrossRef]

69. Giuggioli, N.R.; Girgenti, V.; Peano, C. Qualitative Performance and Consumer Acceptability of Starch Films for the Blueberry Modified Atmosphere Packaging Storage. Pol. J. Food Nutr. Sci. 2017, 67, 129-136. [CrossRef]

70. Sun, J.; Sabbaghi, N.; Ashton, W. Green supply chain formation through by-product synergies. IEEE Trans. Eng. Manag. 2017, 64, 70-82. [CrossRef]

71. Labuschagne, C.; Brent, A.C.; van Erck, R.P.G. Assessing the sustainability performances of industries. J. Clean. Prod. 2015, 13, 373-385. [CrossRef] 
72. Van Bommel, H.W.M. A conceptual framework for analyzing sustainability strategies in industrial supply networks from an innovation perspective. J. Clean. Prod. 2011, 19, 895-904. [CrossRef]

73. Parris, T.M.; Kates, R.W. Characterizing and measuring sustainable development. Annu. Rev. Environ. Resour. 2003, 28, 77-83. [CrossRef]

74. Eveleens, C.; van Rijnsoever, F.; Niesten, E. How network-based incubation helps start-up performance: A systematic review against the background of management theories. J. Technol. Transf. 2016, 42, 676-713. [CrossRef]

75. Lavie, D. The competitive advantage of interconnected firms: An extension of the resource-based view. Acad. Manag. Rev. 2006, 31, 638-658. [CrossRef]

76. Collier, Z.A.; Connelly, E.B.; Polmateer, T.L.; Lambert, J.H. Value chain for next-generation biofuels: Resilience and sustainability of the product life cycle. Environ. Syst. Decis. 2017, 37, 22-33. [CrossRef]

77. Greenspan, A. The growing need for skills in the 21st century. BIS Rev. 2001, 56, 1-3.

78. Vermeulen, W.J.V.; Seuring, S. Introduction: Sustainability through the market- the impacts of sustainable supply chain management. Sustain. Dev. 2009, 17, 269-273. [CrossRef]

79. Pero, M.; Moretto, A.; Bottani, E.; Bigliardi, B. Environmental collaboration for sustainability in the construction industry: An exploratory study in Italy. Sustainability 2017, 9, 125. [CrossRef]

80. Fugiel, A.; Burchart-Korol, D.; Czaplicka-Kolarz, K.; Smolinski, A. Environmental impact and damage categories caused by air pollution emissions from mining and quarrying sectors of European countries. J. Clean. Prod. 2017, 143, 159-168. [CrossRef]

81. Deif, A.M. A system model for green manufacturing. J. Clean. Prod. 2011, 19, 1553-1559. [CrossRef]

82. Aid, G.; Eklund, M.; Anderberg, S.; Baas, L. Expanding roles for the Swedish waste management sector in inter-organizational resource management. Resour. Conserv. Recycl. 2017, 124, 85-97. [CrossRef]

83. Capone, R.; Bilali, H.E.; Bottalico, F. Assessing the Sustainability of Typical Agro-Food Products: Insights from Apulia Region, Italy. New Medit. 2016, 15, 28-35.

84. Chinomona, E.; Omoruyi, O. The influence of CSR, innovation and supply chain partnership on firm competitiveness. Risk Gov. Control Financ. Markets Inst. 2016, 6, 345-354. [CrossRef]

85. Dev, N.K.; Shankar, R. Using interpretive structure modeling to analyze the interactions between environmental sustainability boundary enablers. Benchmarking 2016, 23, 601-617. [CrossRef]

86. Espinoza Pïrez, A.T.; Camargo, M.; Narvïez Rincïn, P.C.; Alfaro Marchant, M. Key challenges and requirements for sustainable and industrialized biorefinery supply chain design and management: A bibliographic analysis. Renew. Sustain. Energy Rev. 2017, 69, 350-359. [CrossRef]

87. Furlan Matos Alves, M.W.; Lopes de Sousa Jabbour, A.B.; Kannan, D.; Chiappetta Jabbour, C.J. Contingency theory, climate change, and low-carbon operations management. Supply Chain Manag. 2017, 22, 223-236. [CrossRef]

88. García-Arca, J.; González-Portela Garrido, A.T.; Prado-Prado, J.C. “Sustainable packaging logistics". The link between sustainability and competitiveness in supply chains. Sustainability 2017, 9, 1098. [CrossRef]

89. Gold, S.; Kunz, N.; Reiner, G. Sustainable Global Agrifood Supply Chains: Exploring the Barriers. J. Ind. Ecol. 2017, 21, 249-260. [CrossRef]

90. Hwang, B.-N.; Huang, C.-Y.; Wu, C.-H. A TOE approach to establish a green supply chain adoption decision model in the semiconductor industry. Sustainability 2016, 8, 168. [CrossRef]

91. Jernström, E.; Karvonen, V.; Kässi, T.; Kraslawski, A.; Hallikas, J. The main factors affecting the entry of SMEs into bio-based industry. J. Clean. Prod. 2017, 141, 1-10. [CrossRef]

92. Jin, M.; Tang, R.; Ji, Y.; Liu, F.; Gao, L.; Huisingh, D. Impact of advanced manufacturing on sustainability: An overview of the special volume on advanced manufacturing for sustainability and low fossil carbon emissions. J. Clean. Prod. 2017, 161, 69-74. [CrossRef]

93. Korhonen, J.; Pätäri, S.; Toppinen, A.; Tuppura, A. The role of environmental regulation in the future competitiveness of the pulp and paper industry: The case of the sulfur emissions directive in Northern Europe. J. Clean. Prod. 2015, 108, 864-872. [CrossRef]

94. Kozlowski, A.; Searcy, C.; Bardecki, M. Corporate sustainability reporting in the apparel industry an analysis of indicators disclosed. Int. J. Product. Perf. Manag. 2015, 64, 377-397. [CrossRef]

95. Lin, K.C.; Shyu, J.Z.; Ding, K. A cross-strait comparison of innovation policy under industry 4.0 and sustainability development transition. Sustainability 2017, 9, 786. [CrossRef] 
96. Long, T.B.; Blok, V.; Coninx, I. Barriers to the adoption and diffusion of technological innovations for climate-smart agriculture in Europe: Evidence from the Netherlands, France, Switzerland and Italy. J. Clean. Prod. 2016, 112, 9-21. [CrossRef]

97. Makiya, I.K.; Fraisse, C.W. Sustainability initiatives driving supply chain: Climate governance on beef production system. J. Technol. Manag. Innov. 2015, 10, 215-224. [CrossRef]

98. Missimer, M.; Robèrt, K.-H.; Broman, G. A strategic approach to social sustainability-Part 2: A principle-based definition. J. Clean. Prod. 2017, 140, 42-52. [CrossRef]

99. O'Rourke, D.; Strand, R. Patagonia: Driving sustainable innovation by embracing tensions. Calif. Manag. Rev. 2017, 60, 102-125. [CrossRef]

100. Polizzi di Sorrentino, E.; Woelbert, E.; Sala, S. Consumers and their behavior: State of the art in behavioral science supporting use phase modeling in LCA and ecodesign. Int. J. Life Cycle Assess. 2016, 21, 237-251. [CrossRef]

101. Sala, S.; Anton, A.; McLaren, S.J.; Notarnicola, B.; Saouter, E.; Sonesson, U. In quest of reducing the environmental impacts of food production and consumption. J. Clean. Prod. 2017, 140, 387-398. [CrossRef]

102. Seetharaman, A.; Sandanaraj, L.L.; Moorthy, M.K.; Saravanan, A.S. Enterprise framework for renewable energy. Renew. Sustain. Energy. Rev. 2016, 54, 1368-1381. [CrossRef]

103. Silvestre, B.S. Sustainable supply chain management in emerging economies: Environmental turbulence, institutional voids and sustainability trajectories. Int. J. Prod. Econ. 2015, 167, 156-169. [CrossRef]

104. Sun, I.; Kim, S.Y. Energy R\&D towards sustainability: A panel analysis of government budget for energy R\&D in OECD countries (1974-2012). Sustainability 2017, 9, 617. [CrossRef]

105. Testa, M.; Malandrino, O.; Sessa, M.R.; Supino, S.; Sica, D. Long-term sustainability from the perspective of cullet recycling in the container glass industry: Evidence from Italy. Sustainability 2017, 9, 1752. [CrossRef]

106. Torjai, L.; Nagy, J.; Bai, A. Decision hierarchy, competitive priorities and indicators in large-scale "herbaceous biomass to energy" supply chains. Biomass Bioenergy 2015, 80, 321-329. [CrossRef]

107. Tseng, M.-L.; Bui, T.-D. Identifying eco-innovation in industrial symbiosis under linguistic preferences: A novel hierarchical approach. J. Clean. Prod. 2017, 140, 1376-1389. [CrossRef]

108. Verghese, K.; Lewis, H.; Lockrey, S.; Williams, H. Packaging's Role in Minimizing Food Loss and Waste across the Supply Chain. Packag. Technol. Sci. 2015, 28, 603-620. [CrossRef]

109. Khan, S.A.R.; Dong, Q. Impact of green supply chain management practices on firms' performance: An empirical study from the perspective of Pakistan. Environ. Sci. Pollut. Res. 2017, 24, 16829-16844. [CrossRef] [PubMed]

110. Burki, U.; Dahlstrom, R. Mediating effects of green innovations on interfirm cooperation. Australas. Mark. J. 2017, 25, 149-156. [CrossRef]

111. Pipatprapa, A.; Huang, H.; Huang, C. A novel environmental performance evaluation of Thailand's food industry using structural equation modeling and fuzzy analytic hierarchy techniques. Sustainability 2016, 8, 246. [CrossRef]

112. Liu, S.; Chang, Y. Manufacturers' closed-loop orientation for green supply chain management. Sustainability 2017, 9, 222. [CrossRef]

113. Katsikeas, C.S.; Leonidou, C.N.; Zeriti, A. Eco-friendly product development strategy: Antecedents, outcomes, and contingent effects. J. Acad. Mark. Sci. 2016, 44, 660-684. [CrossRef]

114. Souto, J.E.; Rodriguez, A. The problems of environmentally involved firms: Innovation obstacles and essential issues in the achievement of environmental innovation. J. Clean. Prod. 2015, 101, 49-58. [CrossRef]

115. Ravi, V. Analysis of interactions among barriers of eco-efficiency in electronics packaging industry. J. Clean. Prod. 2015, 101, 16-25. [CrossRef]

116. Chappin, M.M.H.; Cambre, B.; Vermeulen, P.A.M.; Lozano, R. Internalizing sustainable practices: A configurational approach on sustainable forest management of the Dutch wood trade and timber industry. J. Clean. Prod. 2015, 107, 760-774. [CrossRef]

117. Zailani, S.; Govindan, K.; Iranmanesh, M.; Shaharudin, M.R.; Chong, Y.S. Green innovation adoption in automotive supply chain: The Malaysian case. J. Clean. Prod. 2015, 108, 1115-1122. [CrossRef]

118. Grekova, K.; Calantone, R.J.; Bremmers, H.J.; Trienekens, J.H.; Omta, S.W.F. How environmental collaboration with suppliers and customers influences firm performance: Evidence from Dutch food and beverage processors. J. Clean. Prod. 2016, 112, 1861-1871. [CrossRef] 
119. Li, W.; Chow, P.; Choi, T.; Chan, H. Supplier integration, green sustainability programs, and financial performance of fashion enterprises under global financial crisis. J. Clean. Prod. 2016, 135, 57-70. [CrossRef]

120. Hayami, H.; Nakamura, M.; Nakamura, A.O. Economic performance and supply chains: The impact of upstream firms' waste output on downstream firms' performance in Japan. Int. J. Prod. Econ. 2015, 160, 47-65. [CrossRef]

121. Longoni, A.; Cagliano, R. Environmental and social sustainability priorities: Their integration in operations strategies. Int. J. Oper. Prod. Manag. 2015, 35, 216-245. [CrossRef]

122. Kahkonen, A.; Lintukangas, K.; Ritala, P.; Hallikas, J. Supplier collaboration practices: Implications for local firm innovation process. Eur. Bus. Rev. 2017, 29, 402-418. [CrossRef]

123. Guo, D.; Chen, H.; Long, R.; Lu, H.; Long, Q.Y. A co-word analysis of organizational constraints for maintaining sustainability. Sustainability 2017, 9, 1928. [CrossRef]

124. Raty, T.; Toppinen, A.; Roos, A.; Riala, M.; Nyrud, A.Q. Environmental policy in the Nordic wood product industry: Insights into firms' strategies and communication. Bus. Strateg. Environ. 2016, 25, 10-27. [CrossRef]

125. Wang, L.; Watanabe, T. Influence of trust on biomass supply decision-making in China. Energies 2017, 10, 1749. [CrossRef]

126. Flores Hernandez, U.; Jaeger, D.; Islas Samperio, J. Bioenergy potential and utilization costs or the supply of forest woody biomass for energetic use at a regional scale in Mexico. Energies 2017, 10, 1192. [CrossRef]

127. Goyal, S.; Esposito, M.; Kapoor, A. Circular Economy Business Models in Developing Economies: Lessons from India on Reduce, Recycle, and Reuse Paradigms. Thunderbird Int. Bus. Rev. 2016, 60, 729-740. [CrossRef]

128. Kulak, M.; Nemecek, T.; Frossard, E.; Gaillard, G. Eco-efficiency improvement by using integrative design and life cycle assessment. The case study of alternative bread supply chains in France. J. Clean. Prod. 2016, 112, 2452-2461. [CrossRef]

129. Peano, C.; Girgenti, V.; Baudino, C.; Giuggioli, N.R. Blueberry supply chain in Italy: Management, innovation and sustainability. Sustainability 2017, 9, 261. [CrossRef]

130. Robinson, W.G.; Chan, P.W.; Lau, T. Sensors and sensibility: Examining the role of technological features in servitizing construction towards greater sustainability. Constr. Manag. Econ. 2016, 34, 4-20. [CrossRef]

131. Sellitto, M.A.; Hermann, F.F. Prioritization of green practices in GSCM: Case study with companies of the peach industry. Gestao Prod. 2016, 23, 871-886. [CrossRef]

132. Diana, G.C.; Chiappetta Jabbour, C.J.; Lopes de Sousa Jabbour, A.B.; Kannan, D. Putting environmental technologies into the mainstream: Adoption of environmental technologies by medium-sized manufacturing firms in Brazil. J. Clean. Prod. 2017, 142, 4011-4018. [CrossRef]

133. Domingo, R.; Aguado, S. Overall environmental equipment effectiveness as a metric of lean and green manufacturing system. Sustainability 2015, 7, 9031-9047. [CrossRef]

134. Chung, C.; Chao, L.; Lou, S. The establishment of a green supplier selection and guidance mechanism with the ANP and IPA. Sustainability 2016, 8, 259. [CrossRef]

135. Hooks, T.; Macken-Walsh, A.; McCarthy, O.; Power, C. The impact of a Value-Based Supply Chain (VBSC) on firm-level viability, sustainability and resilience: Case study evidence. Sustainability 2017, 9, 267. [CrossRef]

136. Calza, F.; Parmentola, A.; Tutore, I. Types of green innovation: Ways of implementation in a non-green industry. Sustainability 2017, 9, 1301. [CrossRef]

137. Beh, L.; Ghobadian, A.; He, Q.; Gallear, D.; O'Regan, N. Second-life retailing: A reverse supply chain perspective. Supply Chain Manag. 2016, 21, 259-272. [CrossRef]

138. Zander, S.; Trang, S.; Kolbe, L.M. Drivers of network governance: A multitheoretic perspective with insights from case studies in the German wood industry. J. Clean. Prod. 2016, 110, 109-120. [CrossRef]

139. Kuokkanen, A.; Mikkila, M.; Kuisma, M.; Kahiluoto, H.; Linnanen, L. The need for policy to address the food system lock-in: A case study on the Finnish contest. J. Clean. Prod. 2017, 140, 933-944. [CrossRef]

140. Testa, F.; Nucci, B.; Iraldo, F.; Apolloni, A.; Daddi, T. Removing obstacles to the implementation of LCA among SMEs: A collective strategy for exploiting recycled wool. J. Clean. Prod. 2017, 156, 923-931. [CrossRef]

141. Sroufe, R. Integration and organizational change towards sustainability. J. Clean. Prod. 2017, 162, 315-329. [CrossRef]

142. Vagnoni, E.; Franca, A.; Porqueddu, C.; Duce, P. Environmental profile of Sardinian sheep milk cheese supply chain: A comparison between two contrasting dairy systems. J. Clean. Prod. 2017, 165, 1078-1089. [CrossRef] 
143. Nilsson, F.R.; Sternberg, H.; Klaas-Wissing, T. Who controls transport emissions and who cares? Investigating the monitoring of environmental sustainability from a logistics service provider's perspective. Int. J. Logist. Manag. 2017, 28, 798-820. [CrossRef]

144. Cui, L. Fuzzy approach to eco-innovation for enhancing business functions: A case study in China. Ind. Manag. Data Syst. 2017, 117, 967-987. [CrossRef]

145. Upstill-Goddard, J.; Glass, J.; Dainty, A.; Nicholson, I. Implementing sustainability in small and medium-sized construction firms: The role of absorptive capacity. Eng. Constr. Archit. Manag. 2016, 23, 407-427. [CrossRef]

146. Sehnem, S.; Oliveira, G.P. Analysis of the supplier and agribusiness relationship. J. Clean. Prod. 2017, 168, 1335-1347. [CrossRef]

147. Dong, L.; Liang, H.; Zhang, L.; Liu, Z.; Gao, Z.; Hu, M. Highlighting regional eco-industrial development: Life cycle benefits of an urban industrial symbiosis and implications in China. Ecol. Model. 2017, 361, 164-176. [CrossRef]

148. Silvestre, B.S. A hard nut to crack! Implementing supply chain sustainability in an emerging economy. J. Clean. Prod. 2015, 96, 171-181. [CrossRef]

149. Asokan, V.A.; Yarime, M.; Esteban, M. Introducing flexibility to complex, resilient socio-ecological systems: A comparative analysis of economics, flexible manufacturing systems, evolutionary biology, and supply chain management. Sustainability 2017, 9, 1091. [CrossRef]

150. Edeseyi, M.E.; Kaita, A.Y.; Harun, R.; Danquah, M.K.; Acquah, C.; Sia, J.K.M. Rethinking sustainable biofuel marketing to titivate commercial interests. Renew. Sustain. Energy Rev. 2015, 52, 781-792. [CrossRef]

151. Edgeman, R.; Wu, Z. Supply chain criticality in sustainable and resilient enterprises. J. Model. Manag. 2016, 11, 869-888. [CrossRef]

152. Jordan, N.R.; Dorn, K.; Runck, B.; Ewing, P.; Williams, A.; Anderson, K.A.; Johnson, G. Sustainable commercialization of new crops for the agricultural bioeconomy. Elementa 2016, 2016, 000081. [CrossRef]

153. O'Connor, M.P.; Zimmerman, J.B.; Anastas, P.T.; Plata, D.L. A strategy for material supply chain sustainability: Enabling a circular economy in the electronics industry through green engineering. ACS Sustain. Chem. Eng. 2016, 4, 5879-5888. [CrossRef]

154. Schaltegger, S.; Etxeberria, I.Á.; Ortas, E. Innovating Corporate Accounting and Reporting for Sustainability-Attributes and Challenges. Sustain. Dev. 2017, 25, 113-122. [CrossRef]

155. Chen, X.; Wang, X.; Chan, H.K. Manufacturer and retailer coordination for environmental and economic competitiveness: A power perspective. Transp. Res. E 2017, 97, 268-281. [CrossRef]

156. Corsatea, T.D.; Giaccaria, S.; Covrig, C.; Zaccarelli, N.; Ardelean, M. RES diffusion and R\&D investments in the flexibilisation of the European electricity networks. Renew. Sustain. Energy Rev. 2016, 55, 1069-1082. [CrossRef]

157. Knight, L.; Pfeiffer, A.; Scott, J. Supply market uncertainty: Exploring consequences and responses within sustainability transitions. J. Purch. Supply Manag. 2015, 21, 167-177. [CrossRef]

158. Horton, P.; Koh, L.; Guang, V.S. An integrated fuzzy theoretical framework to enhance resource efficiency, sustainability and human health in agri-food systems. J. Clean. Prod. 2016, 120, 164-169. [CrossRef]

159. Inigo, E.A.; Albareda, L. Understanding sustainable innovation as a complex adaptive system: A systemic approach to the firm. J. Clean. Prod. 2016, 126, 1-20. [CrossRef]

160. Xia, D.; Yu, Q.; Gao, Q.; Cheng, G. Sustainable technology selection decision-making model for enterprise in supply chain: Based on a modified strategic balanced scorecard. J. Clean. Prod. 2017, 141, 1337-1348. [CrossRef]

161. Chan, H.K.; Yee, R.W.Y.; Dai, J.; Lim, M.K. The moderating effect of environmental dynamism on green product innovation and performance. Int. J. Prod. Econ. 2016, 181, 384-391. [CrossRef]

162. Strandhagen, J.O.; Vallandingham, L.R.; Fragapane, G.; Strandhagen, J.W.; Stangeland, A.B.H.; Sharma, N. Logistic 4.0 and emerging sustainable business models. Adv. Manuf. 2017, 5, 359-369. [CrossRef]

163. Artsiomchyk, Y.; Zhivitskaya, H. Designing sustainable supply chain under innovation influence. IFAC-PapersOnline 2015, 28, 1695-1699. [CrossRef]

164. Bocken, N.M.P.; Rana, P.; Short, S.W. Value mapping for sustainable business thinking. J. Ind. Prod. Eng. 2015, 32, 88-102. [CrossRef]

165. Du, B.; Liu, Q.; Li, G. Coordinating leader-follower supply chain with sustainable green technology innovation on their fairness concerns. Int. J. Environ. Res. Public Health 2017, 14, 1357. [CrossRef] [PubMed] 
166. Goddard, E.; Boaitey, A.; Hailu, G.; Poon, K. Improving sustainability of beef industry supply chains. Br. Food J. 2016, 118, 1533-1552. [CrossRef]

167. Malindretos, G.; Tsiboukas, K.; Argyropoulou-Konstantaki, S. Sustainable wine supply chain and entrepreneurship. The exploitation of by-products in a waste management process. Int. J. Bus. Sci. Appl. Manag. 2016, 11, 34-46.

168. Xie, G.; Yue, W.; Wang, S. Energy efficiency decision and selection of main engines in a sustainable shipbuilding supply chain. Transp. Res. D 2017, 53, 290-305. [CrossRef]

169. Tseng, B.; Huang, C. Sustainable service and energy provision based on agile rule induction. Int. J. Prod. Econ. 2016, 181, 273-288. [CrossRef]

170. Pari, L.; Suardi, A.; Santangelo, E.; García-Galindo, D.; Scarfone, A.; Alfano, V. Current and innovative technologies for pruning harvesting: A review. Biomass Bioenergy 2017, 107, 398-410. [CrossRef]

171. Centobelli, P.; Cerchione, R.; Esposito, E. Environmental sustainability in the service industry of transportation and logistics service providers: Systematic literature review and research direction. Transp. Res. D 2017, 53, 454-470. [CrossRef]

172. Sternberg, H.; Norrman, A. The Physical Internet-review, analysis, and future research agenda. Int. J. Phys. Distrib. Logist. 2017, 47, 736-762. [CrossRef]

(c) 2018 by the authors. Licensee MDPI, Basel, Switzerland. This article is an open access article distributed under the terms and conditions of the Creative Commons Attribution (CC BY) license (http:/ / creativecommons.org/licenses/by/4.0/). 